\author{
UNIVERSIDADE DE SÃO PAULO \\ FACULDADE DE ECONOMIA, ADMINISTRAÇÃO E CONTABILIDADE \\ DEPARTAMENTO DE ECONOMIA \\ PROGRAMA DE PÓS-GRADUAÇÃO EM ECONOMIA
}

\title{
The Effects of Regulation and Competition on the Housing Market from a Structural Model
}

Os Efeitos da Regulação e Competição no Mercado Imobiliário a partir de um Modelo Estrutural

Rômullo Carvalho da Silva

Orientador: Prof. Dr. Danilo Camargo Igliori

São Paulo - Brasil

2017 
Prof. Dr. Marco Antonio Zago

Reitor da Universidade de São Paulo

Prof. Dr. Adalberto Américo Fischmann

Diretor da Faculdade de Economia, Administração e Contabilidade

Prof. Dr. Eduardo Amaral Haddad

Chefe do Departamento de Economia

Prof. Dr. Ariaster Baumgratz Chimeli

Coordenador do Programa de Pós-Graduação em Economia 


\section{The Effects of Regulation and Competition on the Housing Market from a Structural Model}

Os Efeitos da Regulação e Competição no Mercado Imobiliário a partir de um Modelo Estrutural

Dissertação apresentada ao Departamento de Economia da Faculdade de Economia, Administração e Contabilidade da Universidade de São Paulo como requisito parcial para a obtenção do título de Mestre em Ciências.

Orientador: Prof. Dr. Danilo Camargo Igliori

Versão Original

São Paulo - Brasil

2017 
FICHA CATALOGRÁFICA

Elaborada pela Seção de Processamento Técnico do SBD/FEA/USP

Silva, Rômulo Carvalho da

The effects of regulation and competition on the housing market from a structural model / Rômulo Carvalho da Silva. - São Paulo, 2017. $66 \mathrm{p}$.

Dissertação (Mestrado) - Universidade de São Paulo, 2017.

Orientador: Danilo Camargo Igliori.

1. Mercado imobiliário 2. Teoria dos jogos 3. Organização industrial I. Universidade de São Paulo. Faculdade de Economia, Administração e Contabilidade. II. Título.

CDD - 333.3322 


\section{Acknowledgements}

A great friend once told me in one of his reveries: writing a dissertation is writing a novel. The next pages are not even close to that. But what I can say is that, somehow, they also sum up much of what these last years have been: a heck of a journey. And I bumped into some remarkable people, whose opinions contributed a lot to this work.

First I would thank my advisors, Danilo Igliori and Fabio Miessi, for their outstanding guidance, patience, and for giving me intellectual freedom in this work. Their incentives go far beyond these pages. I also benefited from many conversations with other professors. In particular, I am grateful to Ariaster Chimeli for his comments during my qualifier presentations.

Thanks also to Patrick Bayer and Allan Collard-Wexler for receiving me at Duke University. I appreciate all their time, ideas and recommendation, and for giving me the opportunity to take part at classes and workshops. This would not be possible without the funding by The São Paulo Research Foundation (FAPESP) through the grants 2016/086867 and 2016/20345-0.

I am grateful to the friends I made during the Master. From the dark mornings with real analysis to many discussions in the "little coffee room". You've made these years more fun and exciting. To Galo, Mareus, Amarildo, Júlia, Ana, Grazi, Hayato, Pimpinho, Arthur and many others. For all the moments, trips and memories. Such a privilege to go through all of this with you. Thank you for being my family in São Paulo.

Lastly and foremost, I would like to thank my family. For my parents, my deepest gratitude for their unconditional love, encouragement, and efforts made for me to complete this step. You push me forward. 

"Not all those who wander are lost."

J.R.R. Tolkien 



\section{Resumo}

A atividade imobiliária é particularmente influenciada pela regulação do uso da terra. Ao agir como "custos burocráticos" ou explicitamente por meio de pagamentos compensatórios, essas regras normalmente aumentam os custos de construção ao reduzir a oferta e aumentar a demanda de novas residências, o que leva a preços mais altos. Este é o primeiro estudo a modelar o processo de decisão de oferta de residências usando uma abordagem de teoria dos jogos. Para mostrar os efeitos da regulação e da competição nesse setor, eu emprego um modelo de entrada estático que incorpora os fatores de demanda, custo e estratégicos comuns a essa atividade. Eu construí uma base de dados única para a cidade de São Paulo, Brasil, com informações sobre o universo de novos empreendimentos residenciais na cidade, juntamente com um histórico de todas as licenças e alvarás requeridos pelas incorporadoras à Prefeitura para cada projeto. Meus resultados mostram que a regulação tem um papel chave na atividade imobiliária. Para as áreas com atividade mais intensa da cidade, a burocracia no processo de aprovação de novas residências tem um custo média anual de $\mathrm{R} \$ 47$ milhões por firma entrante no mercado.

Palavras-chave: mercado imobiliário, teoria dos jogos, organização industrial 



\section{Abstract}

Real estate activity is notably influenced by local land use regulation. By acting as red tape costs or explicitly through compensatory payments, such rules typically increase construction costs by reducing supply and increasing demand in the housing market, which leads to higher prices. This is the first study to model the decision-making process of housing supply using a game theoretic approach. To shed light on the role of regulation and competition in this industry, I employ a static-entry model that incorporates the demand, cost and strategic factors common to the activity. I built a unique data set for the city of São Paulo, Brazil, with information on the universe of new residential buildings launched in the city, along with a history of all licenses requested by the developers to the government for each project. My empirical results show that the regulation play a key role in developer activity. For the areas with the most intense activity of the city, the bureaucracy in the residential approval process cost annually $\mathrm{R} \$ 47$ millions (US $\$ 14$ millions) by entrant firm.

Keywords: housing market, game theory, empirical industrial organization 



\section{List of Figures}

Figure 1 - Important stages of a residential development . . . . . . . . . . . . 23

Figure 2 - Histogram of Approval delay and Total Period . . . . . . . . . . . . . 24

Figure 3 - Apartments launched and price . . . . . . . . . . . . 25

Figure 4 - Market outcomes for selected local markets . . . . . . . . . . . . . 27

Figure 5 - Number of firms vs \% of Total Revenue and Apartments launched over $2000-2013 \ldots \ldots \ldots \ldots \ldots \ldots$

Figure 6 - Firm Size vs Development Size . . . . . . . . . . . . . . . . . 29

Figure 7 - Approval Delay (in months) of a median project by firm size . . . . . . 30

Figure 8 - Distribution of Firm-Market-Year Share . . . . . . . . . . . . . . 51 



\section{List of Tables}

Table 1 - Statistics of Residential Development Stages (in months) . . . . . . . . 24

Table 2 - Summary Statistics for Local Markets-Aggregated Data . . . . . . . . . 26

Table 3 - Summary Statistics for Developers-Aggregated Data . . . . . . . . . . 28

Table 4 - Other Regulations by local market (\% of projects) . . . . . . . . . . 30

Table 5 - Effects on Apartment Price . . . . . . . . . . . . . 31

Table 6 - Land use regulation effects at the local market level . . . . . . . . . 32

Table 7 - Competition effects at the market level by firm size . . . . . . . . . 33

Table 8 - Demand System Estimation . . . . . . . . . . . . . . 48

Table 9 - Marginal Cost Estimation . . . . . . . . . . . . . . 50

Table 10 - First Step - Logit CCPs Estimates . . . . . . . . . . . . . . 53

Table 11 - Structural Parameters (Point Estimates) . . . . . . . . . . . . 54

Table 12 - Structural Parameters (Monetary Cost, Anually) - Top 5 Markets . . . . 54

Table 13 - Developers Identities . . . . . . . . . . . . . . 66 



\section{Contents}

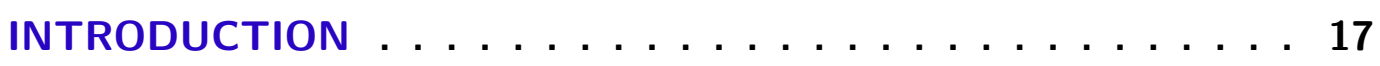

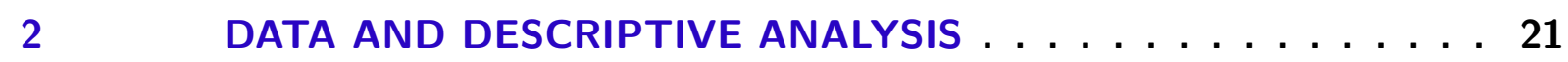

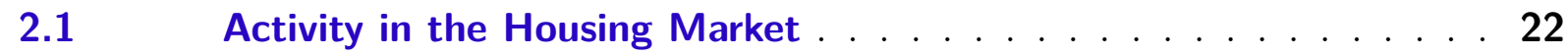

2.2 Descriptive Analysis . . . . . . . . . . . . . 25

3 REDUCED FORM ANALYSIS $\ldots \ldots \ldots \ldots \ldots \ldots$

4 STRUCTURAL MODEL $\ldots \ldots \ldots \ldots \ldots \ldots \ldots$

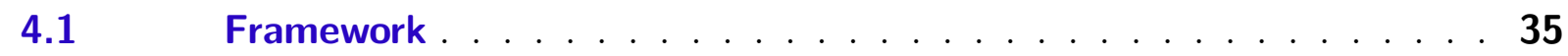

4.2 Components of the Per-Period Payoff Function . . . . . . . . . 37

4.2.1 Consumer Demand and Price Competition Stage . . . . . . . . . . . 37

$4.2 .2 \quad$ Fixed Cost Function . . . . . . . . . . . . . . . . . . . . 39

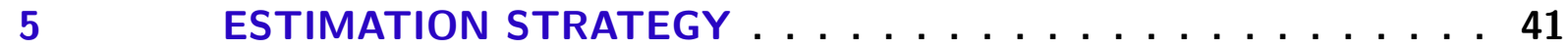

$5.1 \quad$ Competition Stage $\ldots \ldots \ldots \ldots \ldots \ldots \ldots \ldots$

$5.1 .1 \quad$ An example . . . . . . . . . . . . . . . . . 41

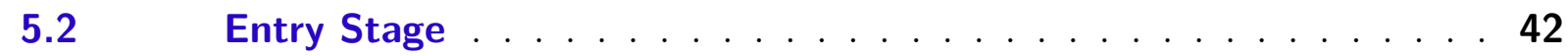

$5.3 \quad$ Dimensionality problem $\ldots \ldots \ldots \ldots \ldots \ldots$

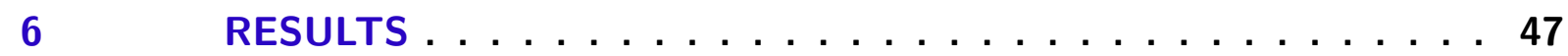

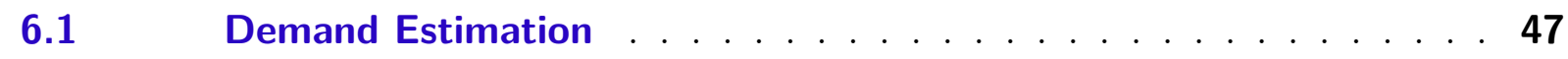

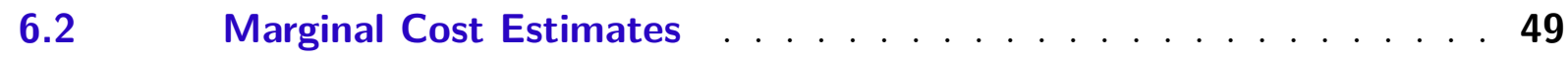

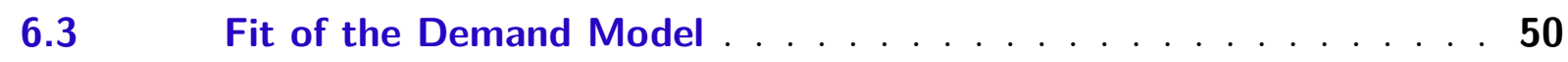

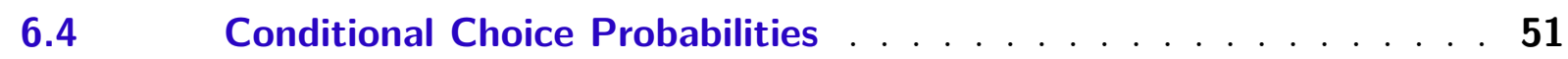

$6.5 \quad$ Structural Parameters . . . . . . . . . . . . . . . 53

6.6 Discussion and Further Work . . . . . . . . . . . . 55

$7 \quad$ CONCLUSION $\ldots \ldots \ldots \ldots \ldots \ldots$

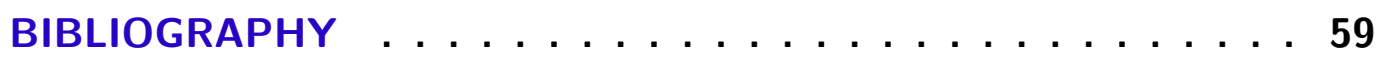

APPENDIX A - DATA CONSTRUCTION . . . . . . 63

APPENDIX B - POTENTIAL ENTRANTS BY MARKET . . . . 65 



\section{Introduction}

Residential land development is a central topic in environmental and urban economics, yet our knowledge on the decision-making process of real estate developers or home builders is limited. Since these firms are responsible for the timing, location and the amount of residences in cities and also alter urban space in ways few other agents are able to, we need to better understand the factors that influence their decision. ${ }^{1}$

Although, a considerable strand in the literature studies the effects of land use regulation on the urban form, on development patterns and, especially, on the price of housing ((MAYER; SOMERVILLE, 2000), (QUIGLEY; RAPHAEL, 2005), (GLAESER; WARD, 2009), (TURNER; HAUGHWOUT; KLAAUW, 2014)), there is a clear lack of papers that have attempted to investigate such questions explicitly modelling developers' decision-making process, as recognized by Garces, Pires et al. (2011) and Gnagey et al. (2012). On the other hand, despite the large breakthrough in the estimation of games in the Industrial Organization (IO) field in recent years, with applications for many industries, ${ }^{2}$ studies that look at the real estate market are scarce. ${ }^{3}$

This study analyzes the role of competition and land use regulation in the housing supply decision. I use a game theoretic approach to shed light on this question that has not been fully addressed in the existing literature. I built a unique panel data set for the city of São Paulo, Brazil, that combines information on the universe of new residential developments launched from 2000 to 2013, with new data gathered from the "São Paulo Municipal System of Proceedings", containing details on the characteristics of each project (residences and the building), the agents involved, along with a complete history of documents transacted between the developers and the municipal government.

I contribute to the previously mentioned literature by employing a full joint entry game, in which developers decide every period whether to launch a residential project and, conditional on entry the market, they set the price of housing. Firms have private information over their own profitability, so that they can not be sure about the actions of competitors. I deal explicitly with the interactions between firms given that an additional developer in the market reduces the profit of another firm. Thus, the model relies on Two

\footnotetext{
1 "Residential development", "apartment building" or "project" as well as "developer" or "firm" will be used interchangeably throughout this study.

${ }^{2}$ For instance, retail (For instance, retail (Jia (2008) and Ardiciacono et al. (2015)), concrete industry (Collard-Wexler (2013)), bulk shipping (Kalouptsidi (2014)), radio industry (Sweeting (2013)), banking (Sanches, Junior e Srisuma (2016a)), hard-disk drive (Igami (2015)).

${ }^{3}$ Barwick e Pathak (2015) is a great exception by analyzing the free-entry impacts on the activity of real estate brokers in the Greater Boston, USA. Also, there are few papers in IO literature that analyze the effects of land use regulations on other industries, such as Suzuki (2013) (lodging) and Nishida (2014) (retail).
} 
Stages: i) at the Competition Stage, the demand system is derived from a discrete choice model of consumer behavior and assuming a Bertrand-Nash equilibrium, I compute the period profit of each firm; ii) these estimates flow into the Entry Stage, which I solve for entry choice probabilities and estimate the fixed cost parameters. ${ }^{4} \mathrm{I}$ allow the fixed cost function to depend on a series of regulation and construction cost variables. I use these estimates to measure the effect of each of these components on market outcomes.

Rather than fully solving the model, most recent papers simplify the estimation of games by adopting a two-step procedure, in which some primitives are estimated "outside" the model and then are incorporated to recover the parameters of interest. This method draws on the findings of Hotz e Miller (1993) and Aguirregabiria e Mira (2002). Therefore, my model combines the well-known methods to estimate games of imperfect information, as in Bajari et al. (2010), with the widely used methods for the estimation of demand and supply relations of differentiated products, as in Berry, Levinsohn e Pakes (1995) and Nevo (2001). Common in this literature, the approach to estimating the model is based on the principle of revealed preference. Assuming that developers maximize expected profits, the decision to launch or not a residential project in a specific market reveals information on costs at the firm-market level. In particular, my methodology is closely related to some applications that model the entry choice with endogenous price setting (e.g., Aguirregabiria e Ho (2012)). ${ }^{5}$

Besides, this study also contributes by analyzing the largest city of a developing country over time and provides the land use regulation effects in a more detailed level, which introduces heterogeneity across project, firms and regions in the city. As pointed by Gyourko e Molloy (2014) in a rich survey on the topic, most articles have used crosssectional data, based on surveys at the jurisdiction or MSA level, and there are practically no applications for outside the U.S., not to mention for developing countries. ${ }^{6}$

In Brazil as in most countries, the municipal government is the entity responsible for establishing rules in the real estate market, using instruments such as the City Building Code and Zoning Laws. These regulations sets the standards for future constructions, affecting the type and amount of future residences. Also, they typically increase fixed costs by acting as red tape costs, due to non-monetary expenses (e.g, approval delays) or explicitly through municipal fees or compensatory payments. Therefore, such rules may create uncertainties and risks that could jeopardize the project in the form of legal problems

\footnotetext{
${ }^{4}$ In general, due to non-availability of price and quantity data, IO papers treat the competition stage using a reduced-form approach, not explicitly modelling the type of competition that firms face when entering the market.

${ }^{5}$ Some studies also employed similar strategies for the endogenous product positioning context (Thomadsen (2005) (fast food industry), Draganska, Mazzeo e Seim (2009) (ice cream market), Sweeting (2013) (radio industry)).

${ }^{6}$ For few examples using different types of regulation, see Fu e Somerville (2001) (China), Bertaud e Malpezzi (2001) (Malaysia) and Bertaud e Brueckner (2005) (India).
} 
and delay in the return of invested capital to developers, thereby culminating in higher house prices for final consumers. These two kinds of regulation (one which introduces a explicit monetary costs on developers and one that delay or lengthen the development process) can aggregate a number of other interventions (MAYER; SOMERVILLE, 2000). Also, even though some projects can also face state and federal regulations, the most difficult part in terms of project approval and restrictions lies with the municipal government. The city of São Paulo provides an interesting case of study because it describes this bureaucratic process well and the analyzed period covers the most intense years for the real estate industry in the city. In addition, the municipal government had a decentralized way to approve residential projects. Consequently, this practice made the process extremely bureaucratic, leading to huge delays and increasing developers complaints. ${ }^{7}$

My empirical approach is twofold. First, to evidence this problem, I employ some reduced forms regressions. The estimates suggest that house prices are positively correlated with my measures of regulation, although the effect diminishes by including firm and region-specific terms. ${ }^{8}$ Areas where residential projects faced more severe regulation in the prior period receive fewer residences and developments in the present, suggesting that firms refrain from entering in these regions. Then, I estimate the structural model, in which I recover the primitives of the game that are consistent with the observed decision rules of the developers. I estimate the parameters of the fixed cost function of firms, which aims to capture the most important elements for a developer to be active in the market-year. The structural estimates are consistent with the reduced form results. For the areas with the most intense real estate activity in the city, the bureaucracy in the residential approval process cost annually $\mathrm{R} \$ 47$ millions in average by each entrant.

Apart from this introduction, the paper is structured as follows: Chapter 2 presents the data and provides the background on the decision-making process in the housing market. In particular, Section 2.2 is devoted to a detailed descriptive analysis, illustrating the sources of heterogeneity in the data that are important to take into account in the methodology. Before showing the structural model and results, Chapter 3 provides a first look to the effects of regulation on developers' activity, from some reduced form regressions. Chapter 4 introduce the structural model, while Chapter 5 outlines the estimation procedure and assumptions. Chapter 6 contains the main results and Chapter 7 concludes.

\footnotetext{
${ }^{7}$ Also, it induced some of the biggest corruption scandals in the City Hall to date: in 2012, prosecutors found that the head of one of these departments received bribes to approve major developments in the city ("Aref's case"), and in 2013 investigations showed that officials received millionaire bribes from major developers in return for tax breaks ("ISS's mafia case"). Some press coverage about these episodes are in Estadao (2013), Folha (2013), Valor (2013).

${ }^{8}$ Anectodal evidence shows that such restrictions rises the house price up to $12 \%$ and costs around U\$ 5 billions for the industry every year. See, for example, Estadao (2011) and Estadao (2014).
} 



\section{Data and Descriptive Analysis}

I use two different sources of data. The first comes from the Brazilian Company of Patrimony Studies ("Embraesp"), a real estate data company, and contains geocoded information about each new residential development launched in the city of São Paulo between 1985 and 2013. ${ }^{1}$ For each property, the names of real estate developers as well as other agents involved (brokers, architects, sellers, etc.) are available, along with many properties' characteristics (total and useful floor area, lot size, launching and closing dates, number of bedrooms and bathrooms, number of garages, number of apartments in the building, etc.), including the apartment price. ${ }^{2}$ The data accounts for both single-family (single houses/horizontal units) and multi-family residences (apartments/vertical units), though the first is clearly underrepresented and there are more discrepancies. Because of this, I exclude all horizontal units in the sample, leaving only with apartments. In addition, although the data is available from 1985, I exclude the years from 1985 to 1999, as this is a period of serious macroeconomic disorganization in Brazil, with a scenario of hyperinflation and also a shortage of real estate financing. Therefore, the final data describe the period from 2000 to 2013.

The Embraesp data set also contains the unique code used by the Prefecture to assign each sector, block and lot (setor/quadra/lote) of the city in the property tax records. Using this variable, I collected information about each development in the data on the website of the "São Paulo Municipal System of Proceedings", which has recently become public. This second data set provides a complete history of documents transacted between property owners and the municipal government. In particular, I can observe all permits requested by developers (before, during and after construction) and the municipality's approvals. Each license contains a detailed description, in which I extract the application and approval date and other information about the land lot and the construction: whether developer had to demolish previous building in the lot or had to make earthworks or landfill, whether it had to pay environmental or zoning compensation, whether it had to construct non-existent sewerage system or even if it had to donate some area to the municipality (to improve the traffic flow in the area, for example).

I matched both data using the property tax record code at the residential development level. I was able to find approximately 95 percent of the properties. To complement, I made two final mergers: i) for developments that had to pay a zoning compensation fee, I collected the amount of this fee; and ii) I matched the data with the 2016 property tax

\footnotetext{
${ }^{1}$ It is worth mentioning that Embraesp does a thorough research on real estate activity, providing data and consultancy to companies, government, financial institutions, media and researchers.

${ }^{2}$ More details in Biderman (2001), the first study to use these data, and Hoyler (2014).
} 
data set to obtain a measure for the land value. Both data sets also became public recently and can be found at São Paulo municipal government's open-data website ("GeoSampa").

My final data set accounts for 3,332 developments corresponding approximately to 360.000 apartments launched over 2000-2013. For more details on how I assembled the data, see the Appendix A.

\subsection{Activity in the Housing Market}

In Brazil, the developers are responsible for the coordination between all phases that lead to a building ahead. Among other obligations, these firms often buy land, finance real estate deals, construct or have constructors who build projects, obtain government approvals, promote marketing plan, oversee the execution of contracted works and services, manage, and finally sell the residences. Occasionally, developers also provide some infrastructure for the area (sewage and water network, for example). Thus, the business risk remains to these agents and, in fact, it starts much earlier than sales.

Due to the potential externalities for the surrounding area, whenever a developer decides to launch and build a project it must obey a specific guideline on which the future construction should fit. The main instrument used by the municipality to establish the rules is the Building Code. This law specifies the standards for constructed structures such as buildings and its main purpose is to "protect public health and safety" (SP, 1992).

Another regulation that developers must face is the Zoning Law. All over the world, Zoning is the set of rules of land use and territorial occupation which defines the type of activities that can be installed in different locations in the city, the size of the constructions, their densities and what should be the relationship between the buildings and the public space. Thus, it may affect the type of housing which developers are willing to build in a specific area, possibly limiting the height, size and the buildable area of a project. There are many restrictions and occupation parameters in different zones within the city, although the Floor Area Ratio (FAR) is perhaps the most important. This instrument is used in many cities to control the construction potential. For example, if the FAR of an area (zone) is 3 , it is possible to build 3 times the land lot size. However, in São Paulo, the Prefecture can allow buildings in some zones to exceed this parameter, up to a maximum FAR, but it charges a monetary compensation from the developers. This restitution is known as Charge for Additional Building Rights ("Outoga Onerosa do Direito de Construir"). From now on, I will refer to it simply as "Zoning Fee".

To obtain the government permission, developers must tailor their projects to these laws. Figure 1 depicts a typical cycle of a residential development with the most important stages of real estate activity. 
Figure 1 - Important stages of a residential development

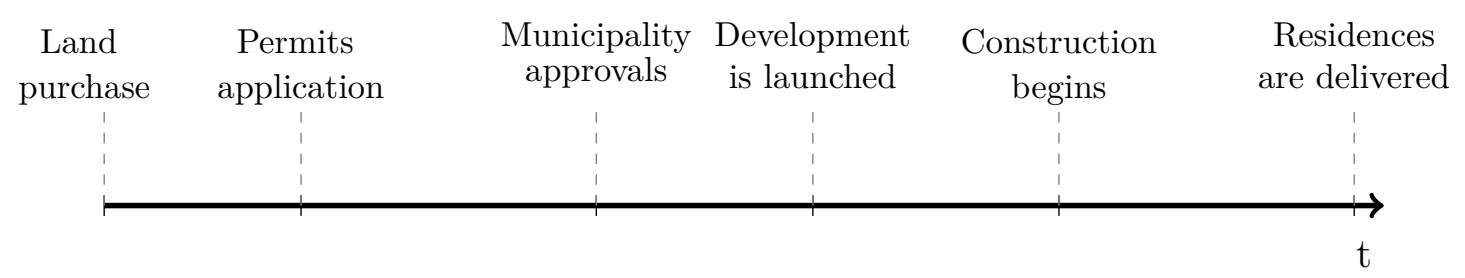

After acquiring the land, which is often the largest cost component, developers request a first license to start planning the project (which I refer as "Permit"), along with a license to perform the construction ("Building Permit"). ${ }^{3}$ At this stage, they have to submit all documents related to the parcel of land (owner's name, property tax breaks, certifications, etc.) as well as a very detailed project of the future building (layout, apartment specifications, architectural plans and engineering, people involved, etc.) to the municipality. This submitted dossier must already be in accordance with the occupation parameters established in the Zoning Law and the guideline in the Building Code. Then, a team of government technicians reviews the application and, if necessary, requires changes until the project is adequate. This stage is the most critical in terms of bureaucracy.

With the legal approvals, the sale stage begins, when the development is launched in the market. Thus, the apartments are sold before construction so that the developer can finance the project. ${ }^{4}$ Note that, since buyers buy the apartment as "a promise", i.e. before construction, the reputation of the developer (product quality and delivery of the residence on time) plays a significant role in consumer choice. When the construction ends and the residences are ready to be occupied, the developer makes his profit after receiving buyer financing or securitization through a bank.

The data allow me to observe the request, approval, launch and closing dates of each apartment building built in the city of São Paulo from 2000 to 2013. Table 1 and Figure 2 report some statistics and the distribution of the duration of these stages, in months. There is a great amount of time between them. Specifically, from the application of the Permit to the municipality issuance, an average residential development in the data takes about 14 months. Usually, developers request the Permit and the Building Permit at the same time (about $55 \%$ of the developments in the data). Because of this, there is no

\footnotetext{
${ }^{3}$ Although there are many other licenses that the developer must apply for (e.g., a final license to verify the construction or "Habite-se"), I will focus on these two licenses ("Alvará de Aprovação de Edificação Nova" and "Alvará de Aprovação de Execução de Edificação Nova, since both understand the greater delays seen in data. For more details on the licenses and this legal process in São Paulo, see SMUL-SP (2016) and Hoyler (2014).

${ }^{4}$ From some conversations with market people, in general, the developer gets an average of $20 \%$ to $40 \%$ of total revenue at launch. But this "Potential Sales Value" varies according to the project, the profile of the buyers and macroeconomic effects. In some cases, especially in periods of boom, some whole buildings can be sold out in a few days.
} 
substantial difference between the two first approval delays in Table 1.

Table 1 - Statistics of Residential Development Stages (in months)

\begin{tabular}{lccccc}
\hline & Mean & Std. Dev. & P25 & P50 & P75 \\
\hline Permit Approval Delay & 13.76 & 14.67 & 5.23 & 9.10 & 16.13 \\
Building Permit Approval Delay & 13.90 & 14.86 & 4.53 & 9.47 & 17.53 \\
Closing date - Launch date & 27.18 & 9.57 & 22.30 & 29.43 & 34.53 \\
Total Period & 51.03 & 22.52 & 37.13 & 45.57 & 58.43
\end{tabular}

Note: Data for 2000-2013. Permit approval delay corresponds to the difference between the approval date of the first license requested to the municipality and the application date. Build Permit is the same, but for the license authorizing the construction. Total Period is the difference between the delivery of the apartment to buyers and the application date for the first license.

Since I do not have specific dates for when the construction began and ended, I can proxy them by the difference between the closing and launch date. This phase corresponds to just over two years and its distribution seems less skewed compared to the approval stage, i.e., the construction time is more homogeneous across projects. The total period, from the Permit request to the closing date, through the construction and sales stages, corresponds to 51 months or just over 4 years. Disregarding the construction phase, almost a third of the process is spent on regulation and bureaucracy.

Figure 2 - Histogram of Approval delay and Total Period
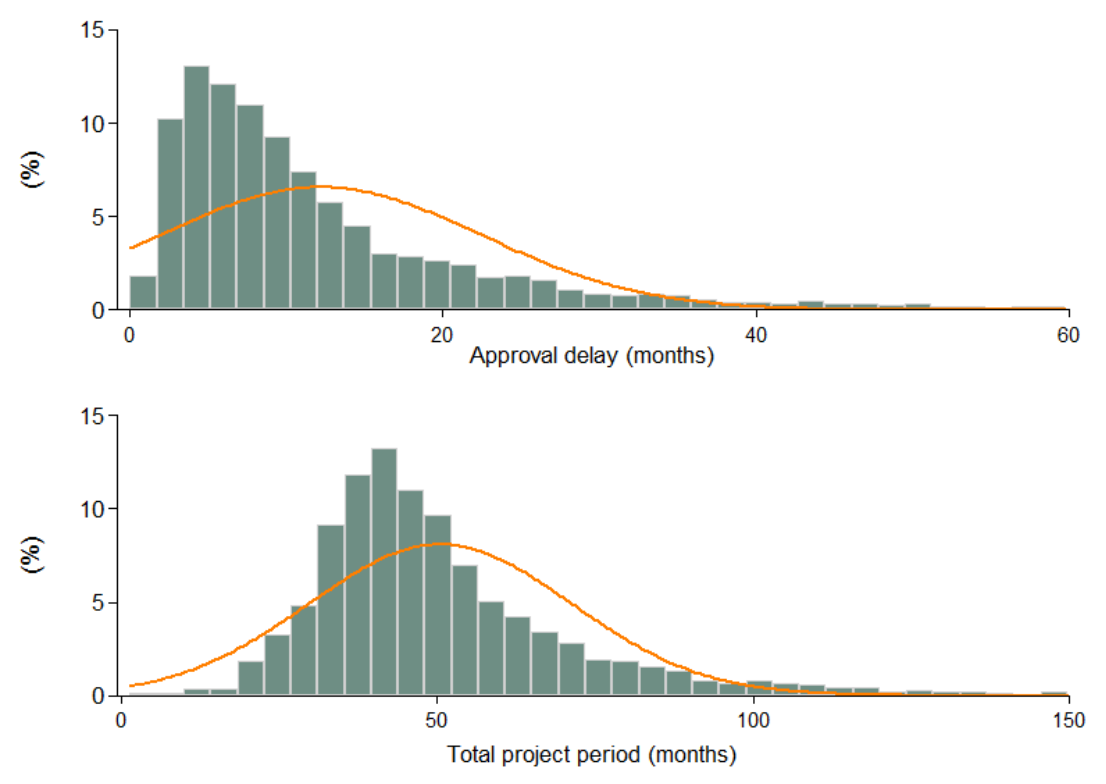

Given that the developers do not know the level of government's requirement for changes in their original projects before granting a final approval, this whole process increases risks and uncertainties as they can compromise project survival by pressuring 
developer's cash flows due to a slower return on invested capital (e.g., in the land lot, wages or marketing). In addition, it causes the firms do not fulfill the delivery of the apartment to buyers on the date established in the purchase agreement, potentially leading to legal problems and lawsuits and affecting the firm's credibility. As a consequence, the final price tends to be higher in order to accommodate such costs and uncertainties.

\subsection{Descriptive Analysis}

Figure 3 describes the supply of new apartments and the evolution of prices over time in São Paulo. We can note the expansion of developments starting from 2006, the year when many developers became public companies. After that, the real estate market went through a boom period from 2009, reaching a peak in 2011. These years marked an expansion period of the federal government's credit policy and by investments in infrastructure, especially in the construction and housing sector. The increasing of credit supply in this period, both for companies and for consumers, established mechanisms to reduce the housing shortage and support the financial development of the real estate sector..$^{5}$

Figure 3 - Apartments launched and price

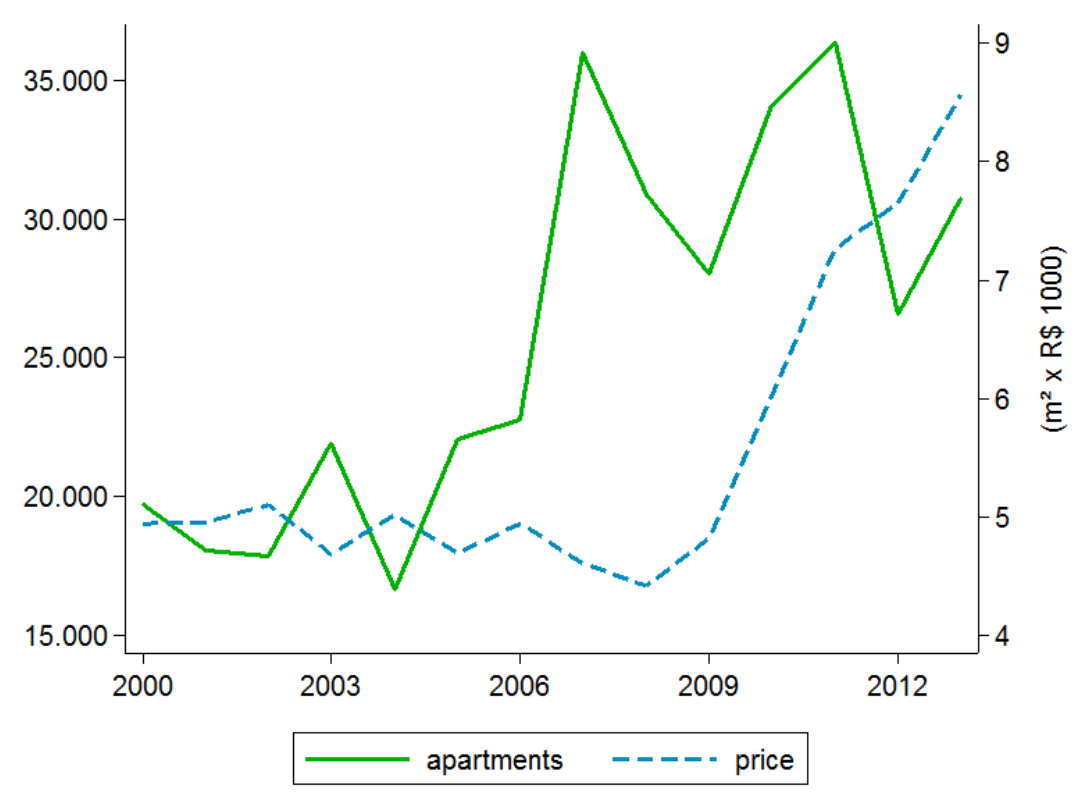

In the analysis, I define the market as the city of São Paulo divided into the geographical areas of Subprefectures, a set of contiguous neighborhoods. These administrative divisions are subordinated to the municipal government and participate in some stages

\footnotetext{
${ }^{5}$ Motivated by the accelerated trajectory of house prices initiated in 2008 , the market boom raised a concern about the existence or not of a bubble in the sector, particularly after the subprime crisis in the U.S.
} 
of the authorization process for new constructions. ${ }^{6}$ Also, many developers end up by focusing their activity on specific parts of the city. This is consistent not only with what I see in the data, but also with market evidence, as in Wissenbach (2008). By doing this, I allow different degrees of competition in these areas, with different set of firms making decisions on them.

I have 28 local markets in the data. Table 2 and Figure 4 try to illustrate the significant heterogeneity between them. An average local market has 244 developments built with 23 thousands of apartments and a few more than 100 firms with at least one development launched from 2000 to 2013. The differences in the trends and scale in Figure 4 between centralized markets (such as Pinheiros or Mooca) and markets in the outskirts of the city (as Itaquera) suggest a different dynamism of real estate activity within the city. In addition, some demand factors in the bottom panel of Table 2 exemplifies the social heterogeneity across these areas.

Table 2 - Summary Statistics for Local Markets-Aggregated Data

\begin{tabular}{lccccc}
\hline & Mean & Std. Dev. & P25 & P50 & P75 \\
\hline \# developments & 244.0 & 131.1 & 161 & 231 & 386 \\
\# apartments & 23,090 & 9,355 & 13,481 & 26,077 & 27,438 \\
\# firms competing & 104.3 & 46.08 & 77 & 99 & 154 \\
\hline Other local market characteristics & & & & & \\
\hline Medium Income (R $\$)$ & $4,152.60$ & $1,645.07$ & $2,946.48$ & $4,136.14$ & $5,993.61$ \\
Population (x1000) & 378.21 & 114.90 & 291.87 & 369.50 & 437.59 \\
Total Area $\left(\mathrm{Km}^{2}\right)$ & 37.41 & 23.34 & 24.30 & 31.70 & 42.80 \\
Density (Hab/ $\left.\mathrm{Km}^{2}\right)$ & 11,077 & 3,995 & 9,071 & 11,587 & 13,742 \\
\hline \hline
\end{tabular}

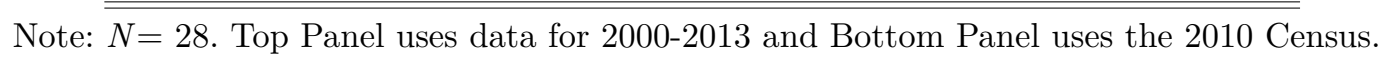

The real estate industry is often characterized by having many agents involved due to few barriers to entry. This is illustrated in the data, in which there are a total of 758 developers with at least one apartment building launched during the period. Simply put, to become a developer one needs, mainly, a sufficient amount of money to purchase the land. One can think that there are three types of firms in this sector: the largest developers, most public companies, with projects throughout the country and with great investment capacity; the medium-sized or local ones, which generally have an advantage of greater know-how of the local market, but with investment constraints; and the small ones, which launch very few developments, focusing on apartments for a specific type of buyers (lower middle class, in general)(CUNHA, 2014).

\footnotetext{
${ }^{6}$ As stated by the municipal Law N ${ }^{0} 13.399 / 2002$. The Prefecture has Departments responsible for the analysis and approval of big constructions (more than $1500 \mathrm{~m}^{2}$ of built area), while the Subprefectures approve small constructions.
} 
Figure 4 - Market outcomes for selected local markets
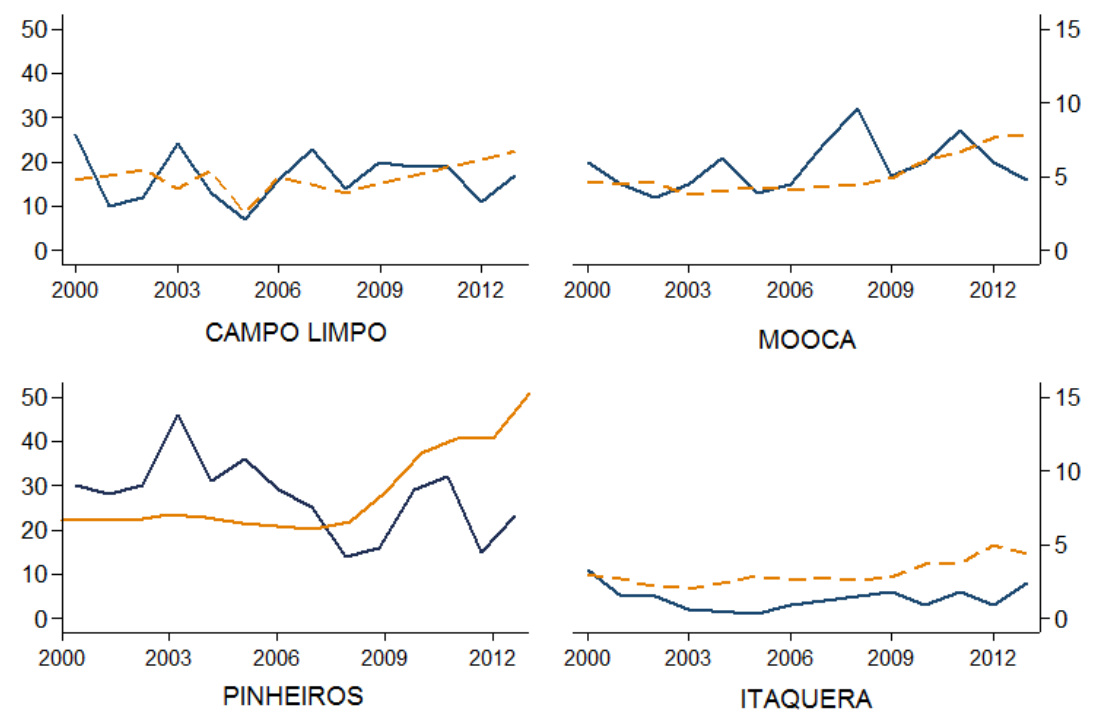

developments

----- price $\left(m^{2} \times 1000\right)$

Note: Data for 2000-2013.

Number of developments in left-hand scale and apartment prices in right-hand scale.

To better see this, I divided the firms using the quartiles of the potential sales revenue distribution during the period. ${ }^{7}$ The top panel in Table 3 reports some statistics for the largest developers (Brookfield, Camargo Correa, Cyrela, EZ Tec, Even, Gafisa, PDG Realty and Tecnisa) in comparison with the firms in other quartiles (bottom panel). The difference is striking: on average, a large developer has many projects spread around the city, having entered at least once in 20 markets, with 126 developments launched, which is equivalent to about $R \$ 7.6$ billion of potential revenue, while a mean developer in other quartiles entered in 5 markets, launched 12 developments and reached a potential revenue of $\mathrm{R} \$ 527$ millions over the period.

These 8 developers in the Top Quartile are responsible for around $40 \%$ of all apartments launched in the city during this period and together they transacted an amount of $\mathrm{R} \$ 72$ billions. Figure 5 shows this concentration and market power among developers' quartiles. About 550 small developers at the Bottom Quartile (nearly $73 \%$ of all firms in the data) launched $16 \%$ of all new apartments, which represents only $11 \%$ of the total of potential revenue in the period.

To illustrate the difference of residential developments between firms, Figure 6 plots the frequency of projects by the distribution of size of the land lot and the number of stories in the building according to the size of the firm. Large developers have more power to invest in large lots, so they build more homes in higher buildings, reducing

\footnotetext{
${ }^{7}$ This potential revenue is the number of units in the development multiplied by the price of the apartment.
} 
Table 3 - Summary Statistics for Developers-Aggregated Data

\begin{tabular}{|c|c|c|c|c|c|}
\hline & Mean & Std. Dev. & $\mathrm{P} 25$ & $\mathrm{P} 50$ & P75 \\
\hline \multicolumn{6}{|l|}{ Developers (Top quartile) $N=8$} \\
\hline \# of Markets which is present & 19.16 & 4.418 & 14 & 22 & 23 \\
\hline No. of Developments & 125.8 & 43.17 & 69 & 143 & 161 \\
\hline No. of Apartments & 21,109 & 9,513 & 8,983 & 20,238 & 29,728 \\
\hline Total of Useful Floor Area (in $1000 \mathrm{~m}^{2}$ ) & $3,612.33$ & $1,547.67$ & $1,880.65$ & $3,672.72$ & $4,926.85$ \\
\hline Potential Revenue (in R\$ MM) & $7,628.50$ & $2,462.58$ & $5,239.29$ & $8,848.16$ & $9,332.94$ \\
\hline \multicolumn{6}{|l|}{ Developers (Q2-Q4 quartiles) $N=750$} \\
\hline \# of Markets which is present & 4.35 & 3.51 & 1 & 3 & 6 \\
\hline No. of Developments & 12.10 & 13.13 & 3 & 7 & 18 \\
\hline No. of Apartments & 1,274 & 1,690 & 162.5 & 485 & 1,490 \\
\hline Total of Useful Floor Area (in $1000 \mathrm{~m}^{2}$ ) & 192.97 & 252.32 & 24.26 & 82.15 & 281.52 \\
\hline Potential Revenue (in R $\$$ MM) & 526.56 & 651.78 & 68.46 & 219.96 & 804.11 \\
\hline
\end{tabular}

Note: Data for 2000-2013.

Figure 5 - Number of firms vs \% of Total Revenue and Apartments launched over 20002013

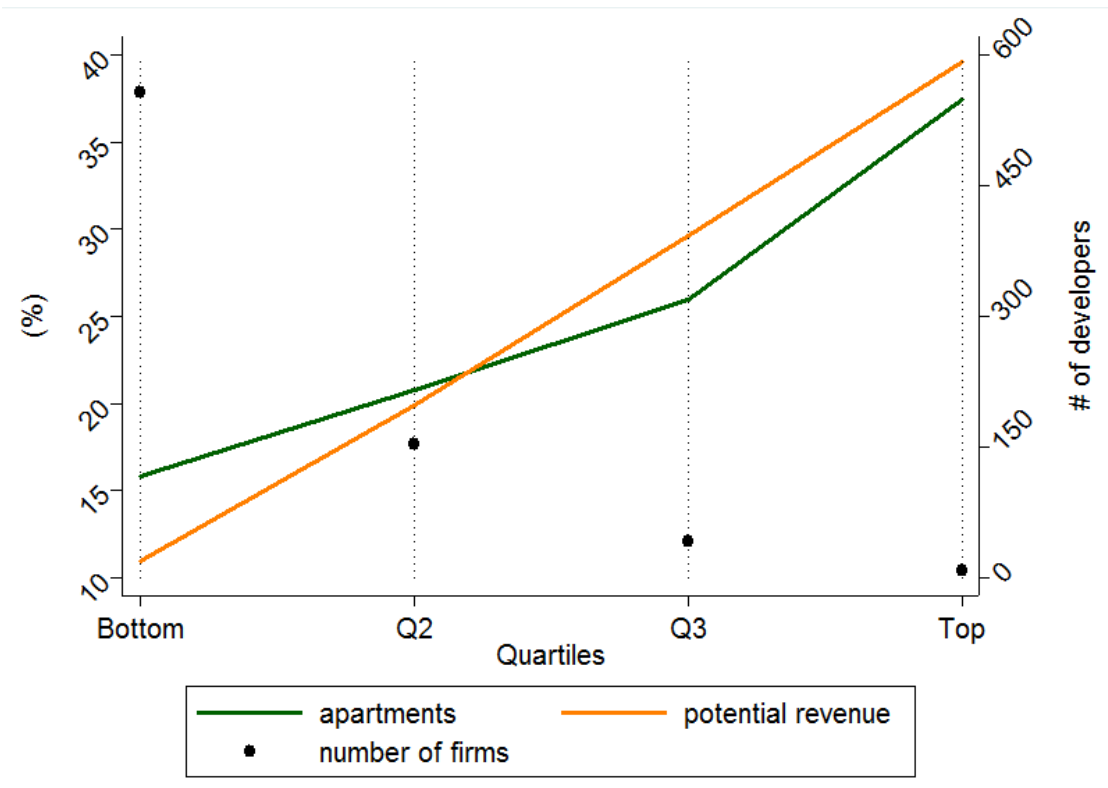

Note: Data for 2000-2013. Firms quartiles defined by developers' potential revenue during the period. 
the marginal costs of building an additional apartment or an extra floor and generating more revenue. On the other hand, smaller firms usually build more compact developments. Therefore, investment power is one of the main barriers or difficulties for new entrants, as it means that larger and more established developers have more bargaining power when purchasing land. ${ }^{8}$ In addition, larger firms have greater "building skills" and are better able to differentiate the apartment in terms of technology and design.

\section{Figure 6 - Firm Size vs Development Size}
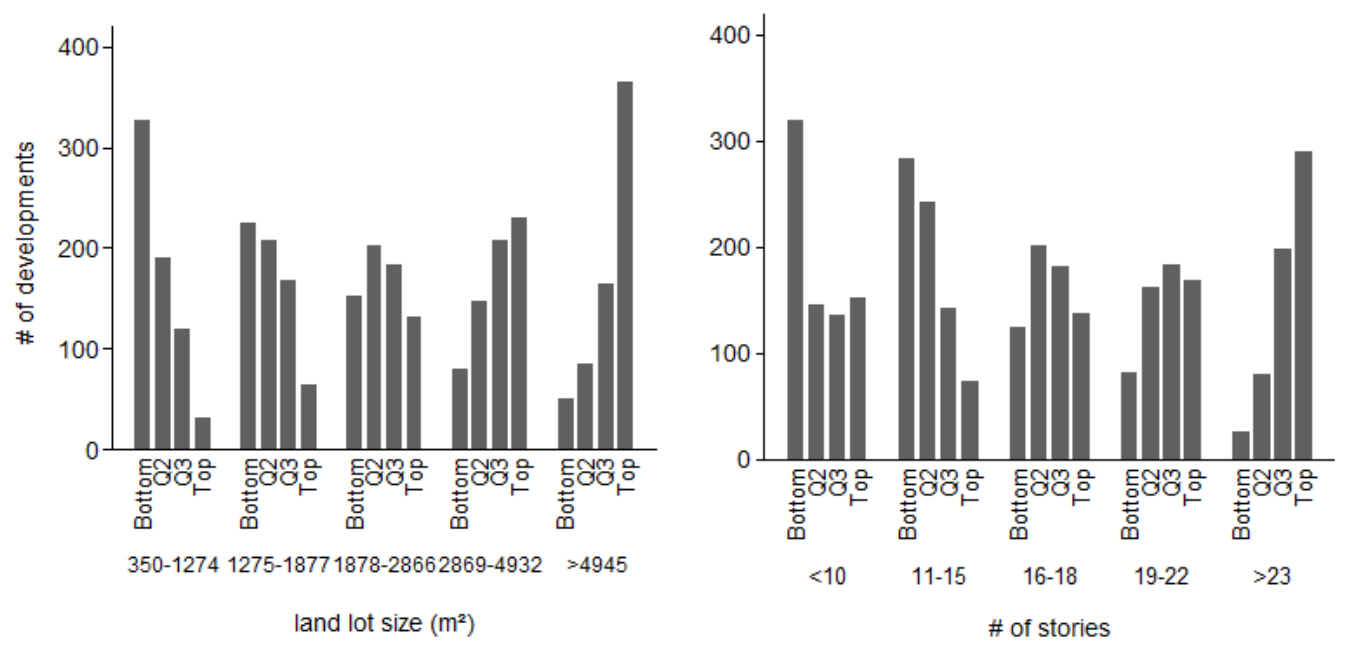

Note: Data for 2000-2013. Firms quartiles defined by developers' potential revenue during the period.

On the land use regulation at the local market-level, Figure 7 presents the Permit approval delay of a median project. Each map illustrates the geographic difference for developers in the Bottom Quartile (small firms) and in the Top Quartile (large firms), using the same definition as before. We can note a great heterogeneity between markets and firms size. Large developers seem to face shorter delays compared to small developers, particularly in more competitive markets (such as Vila Mariana and Pinheiros, central areas in the maps).

In Table 4, I show the proportion of projects that faced other types of land use regulations in each local market. There is a positive correlation between the collection of the Zoning Fee and the main local markets (in the number of developments launched). Nevertheless, we can note a tough regulation of this kind in some "medium" markets, as Vila Maria/Vila Guilherme, where almost $60 \%$ of new projects paid this Fee. My measure of Environmental Compensation refers to any repair (monetary or not) due to environmental damages caused in the area. Developments in markets farther from downtown normally face this reparation. Finally, the need to donate some area (from the project's land lot or not) to improve urbanization or on-site traffic does not constitute an important regulation.

\footnotetext{
${ }^{8}$ In fact, in many local markets, the absence of land availability often leads to a dispute over new land lots, which turn to an "auction" between these firms.
} 
Figure 7 - Approval Delay (in months) of a median project by firm size

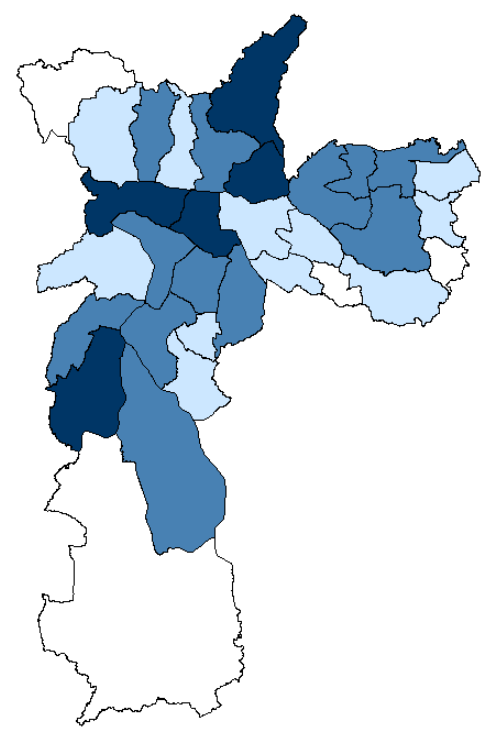

(a) Bottom Quartile

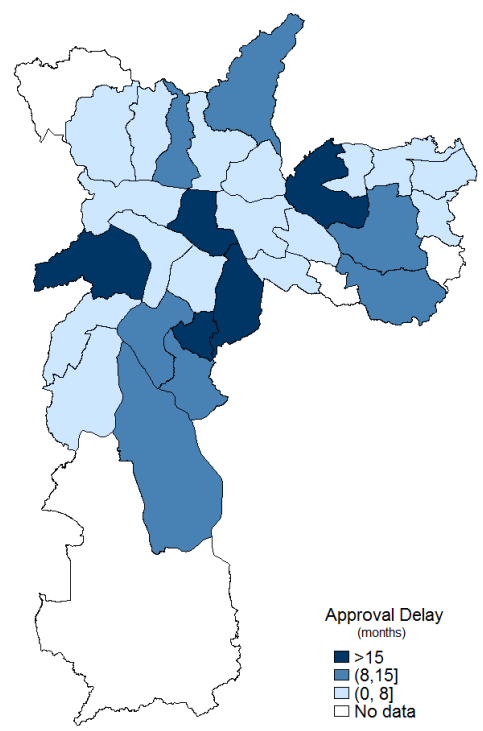

(b) Top Quartile

Note: Data for 2000-2013. Firms quartiles defined by developers' potential revenue during the period.

Table 4 - Other Regulations by local market (\% of projects)

\begin{tabular}{|c|c|c|c|c|}
\hline Local Market & $\begin{array}{c}\text { \# of } \\
\text { developments }\end{array}$ & $\begin{array}{c}\text { Zoning Fee } \\
\text { (outorga onerosa) }\end{array}$ & $\begin{array}{l}\text { Environmental } \\
\text { Compensation }\end{array}$ & $\begin{array}{c}\text { Area } \\
\text { Donation }\end{array}$ \\
\hline ARICANDUVA & 126 & 58.4 & 15.2 & 1.60 \\
\hline BUTANTÃ & 172 & 25.86 & 14.94 & 1.72 \\
\hline CAMPO LIMPO & 231 & 40.87 & 25.22 & 1.30 \\
\hline CAPELA DO SOCORRO & 12 & 25.00 & 25.00 & 0.00 \\
\hline CASA VERDE & 69 & 37.68 & 8.70 & 0.00 \\
\hline CIDADE ADEMAR & 18 & 31.58 & 52.63 & 5.26 \\
\hline ERMELINO MATARAZZO & 18 & 27.78 & 5.56 & 0.00 \\
\hline FREGUESIA DO Ó & 30 & 35.48 & 12.90 & 0.00 \\
\hline GUAIANASES & 13 & 0.00 & 15.38 & 0.00 \\
\hline IPIRANGA & 209 & 40.10 & 10.14 & 3.38 \\
\hline ITAIM PAULISTA & 18 & 27.78 & 11.11 & 0.00 \\
\hline ITAQUERA & 61 & 4.92 & 9.84 & 4.92 \\
\hline JABAQUARA & 78 & 38.46 & 20.51 & 1.28 \\
\hline JACANA/TREMEMBE & 11 & 18.18 & 27.27 & 18.18 \\
\hline LAPA & 337 & 37.61 & 16.42 & 0.30 \\
\hline M'BOI MIRIM & 18 & 38.89 & 11.11 & 5.56 \\
\hline MOOCA & 268 & 44.53 & 11.32 & 1.89 \\
\hline PENHA & 53 & 22.64 & 5.66 & 0.00 \\
\hline PINHEIROS & 384 & 17.44 & 13.59 & 8.21 \\
\hline PIRITUBA/JARAGUA & 41 & 35.71 & 14.29 & 4.76 \\
\hline SANTANA/TUCURUVI & 161 & 45.68 & 16.05 & 8.02 \\
\hline SANTO AMARO & 200 & 25.25 & 16.67 & 15.15 \\
\hline SAO MATEUS & 10 & 30.00 & 10.00 & 0.00 \\
\hline SAO MIGUEL & 10 & 10.00 & 10.00 & 0.00 \\
\hline SÉ & 194 & 32.11 & 10.00 & 1.05 \\
\hline VILA MARIA/VILA GUILHERME & 70 & 57.97 & 13.04 & 8.70 \\
\hline VILA MARIANA & 443 & 40.04 & 17.90 & 2.01 \\
\hline VILA PRUDENTE & 77 & 42.86 & 24.68 & 3.90 \\
\hline
\end{tabular}




\section{Reduced Form Analysis}

In this Chapter, I estimate some regressions to evidence the effects of land use regulation on the activity of developers and to capture the impacts of real estate competition on market outcomes. Although I do not claim causal relations in these results, they are important in anticipating some of the structural estimation findings.

Table 5 regresses the log of apartment price in my measures of regulation and other construction cost indicators. All specifications have year fixed effects.

Table 5 - Effects on Apartment Price

\begin{tabular}{|c|c|c|c|c|}
\hline dep var: $\log ($ Apartment Price $)$ & (1) & $(2)$ & (3) & (4) \\
\hline \multicolumn{5}{|l|}{ Regulation and other costs } \\
\hline $\log$ (Approval delay) & $\begin{array}{c}0.118^{* * *} \\
(0.020)\end{array}$ & $\begin{array}{c}0.0276^{* * *} \\
(0.008)\end{array}$ & $\begin{array}{c}0.0279^{* * *} \\
(0.009)\end{array}$ & $\begin{array}{c}0.0170^{* *} \\
(0.008)\end{array}$ \\
\hline Zoning Fee & & $\begin{array}{l}0.0246 \\
(0.015)\end{array}$ & $\begin{array}{c}-0.00779 \\
(0.016)\end{array}$ & $\begin{array}{c}0.0301^{* *} \\
(0.015)\end{array}$ \\
\hline Environmental Compensation & & $\begin{array}{c}0.119 * * * \\
(0.023)\end{array}$ & $\begin{array}{c}0.0840^{* * *} \\
(0.024)\end{array}$ & $\begin{array}{c}0.0677^{* * *} \\
(0.022)\end{array}$ \\
\hline Area donation & & $\begin{array}{c}0.114^{* * *} \\
(0.035)\end{array}$ & $\begin{array}{l}0.0450 \\
(0.035)\end{array}$ & $\begin{array}{c}-0.00710 \\
(0.031)\end{array}$ \\
\hline Demolition & & $\begin{array}{c}0.124^{* * *} \\
(0.015)\end{array}$ & $\begin{array}{c}0.0729^{* * *} \\
(0.017)\end{array}$ & $\begin{array}{c}0.0517^{* * *} \\
(0.015)\end{array}$ \\
\hline Sewage Network & & $\begin{array}{c}-0.0828^{* * *} \\
(0.019)\end{array}$ & $\begin{array}{c}-0.0631^{* * *} \\
(0.020)\end{array}$ & $\begin{array}{c}-0.0458^{* *} \\
(0.018)\end{array}$ \\
\hline \multicolumn{5}{|l|}{ Apartment characteristics } \\
\hline \# of Bedrooms & & $\begin{array}{c}0.0870^{* * *} \\
(0.016)\end{array}$ & $\begin{array}{c}0.0980^{* * *} \\
(0.017)\end{array}$ & $\begin{array}{c}0.127^{* * *} \\
(0.016)\end{array}$ \\
\hline \# of Garages & & $\begin{array}{c}0.282^{* * *} \\
(0.020)\end{array}$ & $\begin{array}{c}0.317^{* * *} \\
(0.0237)\end{array}$ & $\begin{array}{c}0.265^{* * *} \\
(0.021)\end{array}$ \\
\hline Useful area (in $\mathrm{m}^{2}$ ) & & $\begin{array}{c}0.00407^{* * *} \\
(0.0005)\end{array}$ & $\begin{array}{c}0.00259^{* * *} \\
(0.0005)\end{array}$ & $\begin{array}{c}0.00284^{* * *} \\
(0.0005)\end{array}$ \\
\hline \# of Elevators & & $\begin{array}{c}0.0966^{* * *} \\
(0.007)\end{array}$ & $\begin{array}{c}0.0801^{* * *} \\
(0.008)\end{array}$ & $\begin{array}{c}0.0657^{* * *} \\
(0.007)\end{array}$ \\
\hline Land lot size & & $\begin{array}{c}-0.158^{* * *} \\
(0.009)\end{array}$ & $\begin{array}{c}-0.179^{* * *} \\
(0.013)\end{array}$ & $\begin{array}{c}-0.121^{* * *} \\
(0.012)\end{array}$ \\
\hline Developer Fixed Effect & No & No & Yes & Yes \\
\hline Local market linear trend & No & No & No & Yes \\
\hline $\begin{array}{l}\text { Observations } \\
R^{2}\end{array}$ & $\begin{array}{l}3,268 \\
0.030\end{array}$ & $\begin{array}{l}3,265 \\
0.830\end{array}$ & $\begin{array}{l}3,265 \\
0.908\end{array}$ & $\begin{array}{l}3,265 \\
0.925\end{array}$ \\
\hline \multicolumn{5}{|c|}{$\begin{array}{l}\text { Note: Data for 2000-2013. All regressions have year fixed effect. Dependent variable is the } \\
\text { price of the apartment in log. Approval delay in months. Environmental Compensation: } \\
\text { number of developments that had to compensate for environmental damages of any kind. } \\
\text { Area donation: number of developments in which the developer had to donate any land } \\
\text { parcel to municipality for any compensation; Zoning Fee: number of project that had to } \\
\text { pay Charges for Additional Building Rights (outorga onerosa) due to Zoning restrictions. } \\
\text { Clustered s.e. by development are reported in parenthesis. }\left({ }^{* *}\right) \text { Significant at } 1 \% ;(* *) \\
\text { significant at } 5 \% ;(*) \text { significant at } 10 \% \text {. }\end{array}$} \\
\hline
\end{tabular}

Column 1 has only the Permit approval delay as explanatory variable and has an impact of around $12 \%$ in the price of the apartment. Surprisingly, it is the same effect found in qualitative studies (see Estadao (2014)). However, the effect decreases when I 
control for the characteristics of the residence and the building and by including developer fixed effect in the other columns, although the coefficient remains positive and significant. This fixed effect tries to capture "quality" or other firm-specific attribute invariant over time. Note that I am conditioning to the size of land lot, which is important since large terrains are associated with large projects, which might face greater delays. My preferred specification is in Column 4, which I add a linear trend for each local market in order to eliminate other effects from exogenous factors. Besides approval delays, the Zoning Fee and the environmental compensation has both positive and significant impacts on house price, as expected. Apartments in developments that had to pay the Fee are $3 \%$ more expensive. The need for demolition in the lot and the construction of sewage network tries to verify the influence of some construction costs.

Table 6 presents estimates at the local market level. I pool all developments and compute the median approval delay for each market/year. Similarly, I count the number of projects that face other regulations. Then, I compute these regulation variables of each market in the previous year. Each column uses a measure for market outcomes: the number of apartments, number of developments and number of developers. I also include these dependent variables in the past to control for some inertia of real estate activity that is market-specific.

Table 6 - Land use regulation effects at the local market level

\begin{tabular}{|c|c|c|c|}
\hline dep. variable & $\log (\text { apartments })_{m t}$ & $\log (\# \text { developments })_{m t}$ & $\log (\# \text { firms })_{m t}$ \\
\hline Approval Delay $_{m, t-1}$ & $\begin{array}{c}-0.259^{* * *} \\
(0.081)\end{array}$ & $\begin{array}{c}-0.133^{* *} \\
(0.061)\end{array}$ & $\begin{array}{c}-0.126^{* *} \\
(0.056)\end{array}$ \\
\hline Zoning $\mathrm{Fee}_{m, t-1}$ & $\begin{array}{c}-0.0252^{*} \\
(0.013)\end{array}$ & $\begin{array}{c}-0.0420^{* * *} \\
(0.010)\end{array}$ & $\begin{array}{c}-0.0385^{* * *} \\
(0.010)\end{array}$ \\
\hline Enviromental Compensation $_{m, t-1}$ & $\begin{array}{c}-0.0596^{* *} \\
(0.023)\end{array}$ & $\begin{array}{c}-0.0768^{* * *} \\
(0.020)\end{array}$ & $\begin{array}{c}-0.0808^{* * *} \\
(0.020)\end{array}$ \\
\hline Area Donation ${ }_{m, t-1}$ & $\begin{array}{l}-0.127 \\
(0.256)\end{array}$ & $\begin{array}{l}0.0455 \\
(0.177)\end{array}$ & $\begin{array}{c}-0.0123 \\
(0.172)\end{array}$ \\
\hline $\log (\text { apartments })_{m, t-1}$ & $\begin{array}{c}0.275^{* * *} \\
(0.061)\end{array}$ & & \\
\hline $\log (\mathrm{N} \text { of developments })_{m, t-1}$ & & $\begin{array}{c}0.507^{* * *} \\
(0.058)\end{array}$ & \\
\hline $\log (\mathrm{N} \text { of firms })_{m, t-1}$ & & & $\begin{array}{c}0.499 * * * \\
(0.054)\end{array}$ \\
\hline Local market linear trend & Yes & Yes & Yes \\
\hline $\begin{array}{l}\text { Observations } \\
R^{2}\end{array}$ & $\begin{array}{c}274 \\
0.644\end{array}$ & $\begin{array}{c}274 \\
0.773\end{array}$ & $\begin{array}{c}274 \\
0.779\end{array}$ \\
\hline
\end{tabular}

Note: Data for 2000-2013. All regressions have time fixed effect. Dependent variables are: i) total of apartments launched by market/year; ii) total of residential developments by market/year; iii) number of developers. Approval Delay is the delay in months for a median development in the market/year. Environmental Compensation: number of developments that had to compensate for environmental damages of any kind. Area donation: number of developments in which the developer had to donate any land parcel to municipality for any compensation; Zoning Fee: number of project that had to pay Charges for Additional Building Rights (outorga onerosa) due to Zoning restrictions. White robust s.e. are reported in parenthesis. $(* * *)$ Significant at $1 \% ;(* *)$ significant at $5 \% ;(*)$ significant at $10 \%$. 
Overall, there is a strong negative effect between the housing supply in the local market if the area faced a more stringent regulation in the previous year. In addition, the regression on the number of firms (third column) indicates that such regulations can be interpreted as a type of barrier to entry. A one-month increase for a median project to be approved in a local market induces a $12 \%$ decrease of firms operating in the same market next year. Thus, developers refrain from entering more regulatory regions.

Finally, in Table 7 I attempt to capture a certain form of spatial interactions that emerges as the result of heterogeneity among developers' reputation and experience. I regress the log of number of apartments that a developer launched in the market/year in the number of competitors (Columns 1-3) and the number of apartments launched by competitors (Columns 4-6) in the same market/year. I interact these variables with a Quartile dummy. The greater the competition in the market, the fewer apartments are launched by a developer $i$. This business stealing effect seems to be stronger in the presence of small and large firms (Bottom and Top quartiles) compared to the presence of a midsize developer. Additionally, large developers are able to negotiate and develop long-term relationships with land owners, allowing potential strategic spatial land use decisions that are not possible for small developers. These estimates show an inter-developer competition - where a strategic move on the part of a large developer in a locality, may block another developer's move possibly due to the fear of local oversupply (BALL, 2003).

Table 7 - Competition effects at the market level by firm size

\begin{tabular}{|c|c|c|c|c|c|c|}
\hline dep. var: $\log (\text { apartments })_{i m t}$ & (1) & (2) & (3) & (4) & (5) & (6) \\
\hline \multicolumn{7}{|l|}{ Number of other developers $s_{m t}$} \\
\hline Bottom Quartile & $\begin{array}{c}-0.430^{* * *} \\
(0.021)\end{array}$ & $\begin{array}{c}-0.366^{* * *} \\
(0.032)\end{array}$ & $\begin{array}{c}-0.168^{* * *} \\
(0.059)\end{array}$ & & & \\
\hline Quartile 2 & $\begin{array}{c}-0.286^{* * * *} \\
(0.020)\end{array}$ & $\begin{array}{c}-0.220^{* * *} \\
(0.031)\end{array}$ & $\begin{array}{c}-0.127^{* * *} \\
(0.048)\end{array}$ & & & \\
\hline Quartile 3 & $\begin{array}{c}-0.191 * * * \\
(0.022)\end{array}$ & $\begin{array}{c}-0.132^{* * *} \\
(0.033)\end{array}$ & $\begin{array}{c}-0.131^{*} \\
(0.070)\end{array}$ & & & \\
\hline Top Quartile & $\begin{array}{l}0.0202 \\
(0.025)\end{array}$ & $\begin{array}{c}0.0799 * * \\
(0.034)\end{array}$ & $\begin{array}{c}-0.145^{* * *} \\
(0.054)\end{array}$ & & & \\
\hline \multicolumn{7}{|c|}{ Apartments by other developers $_{m t}$} \\
\hline Bottom Quartile & & & & $\begin{array}{c}-0.174^{* * *} \\
(0.018)\end{array}$ & $\begin{array}{c}-0.166^{* * *} \\
(0.026)\end{array}$ & $\begin{array}{l}-0.0511 \\
(0.055)\end{array}$ \\
\hline Quartile 2 & & & & $\begin{array}{c}-0.126^{* * *} \\
(0.018)\end{array}$ & $\begin{array}{c}-0.114^{* * *} \\
(0.026)\end{array}$ & $\begin{array}{c}-0.132^{* * *} \\
(0.041)\end{array}$ \\
\hline Quartile 3 & & & & $\begin{array}{c}-0.0872^{* * *} \\
(0.018)\end{array}$ & $\begin{array}{c}-0.0785^{* * *} \\
(0.026)\end{array}$ & $\begin{array}{l}-0.0117 \\
(0.057)\end{array}$ \\
\hline Top Quartile & & & & $\begin{array}{c}-0.0102 \\
(0.019)\end{array}$ & $\begin{array}{c}-0.00261 \\
(0.027)\end{array}$ & $\begin{array}{l}0.0148 \\
(0.045)\end{array}$ \\
\hline Local market linear trend & No & Yes & Yes & No & Yes & Yes \\
\hline Developer Fixed Effect & No & No & Yes & No & No & Yes \\
\hline Observations & 2,718 & 2,718 & 2,718 & 2,718 & 2,718 & 2,718 \\
\hline$R^{2}$ & 0.262 & 0.306 & 0.590 & 0.248 & 0.317 & 0.589 \\
\hline
\end{tabular}

Note: Data for 2000-2013. All regressions have year fixed effect. Dependent variable is the log of apartments launched by developer/market/year. Firms' quartiles defined by aggregating each developers' potential revenue over the period. White robust s.e. are reported in parenthesis. $(* * *)$ Significant at $1 \% ;(* *)$ significant at $5 \% ;(*)$ significant at $10 \%$. 



\section{Structural Model}

This Chapter describes the features of my structural model. The goal is to investigate the interactions of developers using a typical static entry-game (Bajari et al. (2010)), in which firms' payoffs are influenced by regulatory costs. My framework attempts to consider some real estate market aspects that I outlined in Chapter 2.

Briefly, at the beginning of each period, developers have information about the state variables and simultaneously choose to launch a residential project in the local market. Firms do not have have complete information on competitors' payoff and, consequently, they cannot be certain about their rivals' optimal choices. Therefore, each firm makes the entry decision by maximizing expected payoffs, given its beliefs on other developers' actions. Conditional on this decision, firms set the prices of the apartments in the local market. The payoffs are thus specified as a function of a period profit, derived from a demand system and a price competition behavior, as well as a fixed cost function that it pays if chooses to develop the project. Payoff functions and strategies are furthermore allowed to differ by firm and by local market.

\subsection{Framework}

Before proceeding further, I must introduce some notation. The industry is configured by $i=\{1, \ldots, N\}$ developers/firms and $m=\{1, \ldots, M\}$ local markets/Subprefectures. In each period $t=\{1, \ldots, \bar{T}\}$, there is a potential set of entrants making decisions in each market. ${ }^{1}$ Let $a_{i m t} \in\{0,1\}$ be the binary indicator of the decision "firm $i$ launches a residential development in market $m$ at period $t$ ". I denote $\mathbf{a}_{m t}=\left(a_{1 m t}, \ldots, a_{N m t}\right) \in\{0,1\}^{N_{m}}$ the market structure in $m$ at $t$. This vector describes the market/period entry decision of all potential entrants. I index $\mathbf{a}_{-i m t}=\left(a_{1 m t}, \ldots, a_{i-1 m t}, a_{i+1 m t}, \ldots, a_{N m t}\right)$ as the action profile of all developers but developer $i$.

Every period (year), firms choose actions simultaneously. I assume that before choosing to launch or not the residences, each developer receives a private profitability shock $\mathscr{E}_{i m t}$, drawn independently across firms, market and over time from a distribution $\mathbf{G}_{\mathscr{E}}$, that is public known (by other firms and by the econometrician). This is the source of asymmetric information in the model. The reasons to incorporate private shocks are two-fold: it guarantees that the game has at least one equilibrium in pure strategies (see Doraszelski e Satterthwaite (2010)) and it is convenient to deal with unobservable heterogeneity in firms' actions without generating endogeneity problems.

\footnotetext{
${ }^{1}$ I define a developer as a potential entrant if it has entered at least one period in that local market over the sample period. This set of potential entrants is market-specific, so I denote it by $N_{m}$.
} 
After entry, developers choose prices for the apartments they will offer in $m$ at $t$, conditional on the current market structure $\mathbf{a}_{m t}$ and the value of exogenous variables that affect demand and costs, which I represent by vector $\mathbf{z}_{i m t}$. Price competition determines variable profits for every developer in market/period. Section 4.2 outlines the details of the model of consumer demand and price competition. I denote developer's period payoff by:

$$
\Pi_{i m t}\left(\mathbf{a}_{m t}, \mathbf{z}_{m t}, \mathscr{E}_{i m t}\right)=a_{i m t}\left[\pi_{i m t}\left(\mathbf{a}_{m t}, \mathbf{z}_{m t}\right)+F_{i m t}+\mathscr{E}_{i m t}\right]
$$

which includes the period profit accruing in the price competition stage, upon entry, $\pi_{i m t}\left(\mathbf{a}_{m t}, \mathbf{z}_{m t}\right)$ and the fixed costs associated with building in $m$ at $t, F_{i m t}$. I assume that developer receives 0 if it chooses not to enter. ${ }^{2}$

Since developers have incomplete information on competitors' actions, they will form expectation about other developers' entry choices and prices under each possible market structure configuration. Thus, the expectation is over the private shock and the other firms' actions in the current period. In this setting, strategies can also be represented as ex-ante choice probabilities (i.e., firms' expected actions prior to the realization of $\left.\mathscr{E}_{i m t}\right)$. As usual, I assume that developers' strategies depend only on payoff-relevant state variables, represented by $\left\{\mathbf{a}_{m t}, \mathbf{z}_{i m t}, \mathscr{E}_{i m t}\right\}$.

I denote $\sigma \equiv\left\{\sigma_{i}\left(\mathbf{a}_{m t}, \mathbf{z}_{i m t}\right): i=1, \ldots, N\right\}$ as the vector of strategy functions, one for each developer. Let $\mathbf{V}_{i}^{\sigma}\left(\mathbf{a}_{m t}, \mathbf{z}_{i m t}, \mathscr{E}_{i m t}\right)$ represent the value function for developer $i$ given that other developers behave according to their respective strategies policy in $\sigma$, and given that $i$ also uses best response strategy. Therefore, the expected period payoff, marginalizing out the strategies of the other players using firm's beliefs, is:

$$
\begin{array}{r}
\mathbf{V}_{i}^{\sigma}\left(\mathbf{a}_{m t}, \mathbf{z}_{i m t}, \mathscr{E}_{i m t}\right)=\mathbb{E}_{\mathbf{a}_{-i m t}}\left[\prod_{i m t}\left(\mathbf{a}_{m t}, \mathbf{z}_{m t}, \mathscr{E}_{i m t}\right)\right] \\
=\sum_{\mathbf{a}_{-i m t}} \sigma_{i}\left(\mathbf{a}_{m t}, \mathbf{z}_{i m t}\right)\left[\prod_{i m t}\left(\mathbf{a}_{m t}, \mathbf{z}_{m t}\right)\right]+\mathscr{E}_{i m t}
\end{array}
$$

A Bayesian Nash Equilibrium in this game can be characterized as a vector of best response strategies, $\sigma$, when each developer $i$ maximizes its expected payoffs for each possible state, taking as given other developers' strategies. Mathematically:

$$
\sigma_{i}\left(\mathbf{a}_{m t}, \mathbf{z}_{i m t}\right)=\underset{a_{i m t}}{\arg \max } \mathbb{E}_{\mathbf{a}_{-i m t}}\left[\Pi_{i m t}\left(\mathbf{a}_{m t}, \mathbf{z}_{m t}, \mathscr{E}_{i m t}\right)\right]
$$

\footnotetext{
${ }^{2}$ Indeed, this is a common restriction made by other studies, in order to compute the levels of the action-specific value function. See Pesendorfer e Schmidt-Dengler (2003).
} 


\subsection{Components of the Per-Period Payoff Function}

\subsubsection{Consumer Demand and Price Competition Stage}

To characterize the demand system, assume that there are $M_{m t}$ potential consumers in market $m$ at year $t$. I index consumers by $j$. I define an apartment as the product in this industry. Instead of choosing some way to segment the apartments into categories, which would be arbitrary, I model developers as single-product firms. Thus, when a consumer is choosing which apartments to buy in each local market, she is also deciding from which firm she will purchase the residence. ${ }^{3}$

The indirect utility of an average consumer $j$ who buys an apartment from developer $i$ in local market $m$ at period $t$ is $U_{i m t}^{j}=V_{i m t}^{j}+\vartheta_{i m t}^{j}$, where $V_{i m t}^{j}$ is the mean utility of an apartment offered by developer $i$ or the $j$ 's willingness to pay for the product in that market and $\vartheta^{j}$ is a $j$-specific taste shock which captures consumer heterogeneity in preferences. I also assume that there is an outside option, $i=0$, that can be rationalized as the decision to rent an apartment or buy it in the second-market rather than a new one.

The mean utility has the following notation:

$$
V_{i m t}=X_{i m t}^{\prime} \beta-\alpha p_{i m t}+\xi_{i}+\xi_{m t}+\xi_{t}+\xi_{i m t}
$$

$X_{i m t}$ is a row vector of observable characteristics of each apartment and the building or condominium. In the estimation, it includes the number of bedrooms, number of garages and useful floor area of each apartment, and also the number of buildings, number of storeys and units in each floor and number of elevators in each building. This vector also includes the distances to the closest metro station and park and distance to downtown areas (Sé Square and Paulista Avenue). $p_{i m t}$ is the price of apartment built by $i$ in market $m$ at $t . \xi_{i}$ is a developer fixed-effect that captures quality inherent to the firm which is invariant over time and across local market. $\xi_{m t}$ is a linear trend for each local market and attempts to capture demand shocks that evolve over time in each market and are common for all products. $\xi_{t}$ represents the time fixed component that affects the demand for new apartments in the city, e.g., macroeconomic effects. $\xi_{i m t}$ is an unobservable apartmentspecific shock. I denote the vector of all parameters to be estimated in the demand system by $\theta_{\mathbf{1}}=\left\{\alpha, \beta, \xi_{i}, \xi_{m t}, \xi_{t}\right\}$.

An average consumer $j$ buys an apartment from $i$ if the correspondent utility $U_{i m t}^{j}$ is the highest among all apartments from other developers available in $m$ at $t$, including the

\footnotetext{
${ }^{3}$ As seen in Section 2.2, the "quality" or credibility of the developer seem to play an important role on consumers' decision, given that the purchase happens before construction. Therefore, the model explicit include this market evidence, since developers can be seen as "brands" here.
} 
outside option. To assess the aggregate demand $q_{i m t}$ we need to impose some assumption to integrate individual purchases over the distribution of consumer-preferences denoted by $\vartheta_{\text {imt }}$. Thus, the aggregate demand depends on the probability distribution of this consumer heterogeneity. I consider a multinomial logit structure in each market separately, so that $\vartheta_{i m t}^{j}$ is an independent Type I extreme value random variable. ${ }^{4}$

Let $s_{i m t}$ be the observed market share of firm $i$ in market $m$ at period $t$, i.e., $s_{i m t}=q_{i m t} / M_{m t}$, where the number of consumers, $M_{m t}$, is a measure of the market size and $q_{i m t}$ is the total of new apartments offered by developer $i$ in the market/period. The multinomial logit structure for each market implies the following relationship:

$$
s_{i m t}\left(\mathbf{a}_{m t}, p_{m t} ; \theta_{\mathbf{1}}\right)=\frac{a_{i m t} e^{V_{i m t}}}{1+\left[\sum_{i^{\prime} \in \mathbf{N}_{m t}} a_{i^{\prime} m t} e^{V_{i^{\prime} m t}}\right]}
$$

where $s_{i m t}\left(\mathbf{a}_{m t}, p_{m t} ; \theta_{\mathbf{1}}\right)$ is the predicted market share for each developer in each market/period, ${ }^{5}$ which depends on the vector of all entry decisions of the developers in the market, $\mathbf{a}_{m t}=\left(a_{1 m t}, \ldots, a_{N m t}\right)$, and also on the equilibrium prices that they set, $\left(\mathbf{p}_{1 m t}, \ldots, \mathbf{p}_{N m t}\right)$, if they decide to enter. Note that, from the denominator in Eq. 4.5, an additional entry of other developer in the market reduces the share of firm $i$, so this equation explicitly deal with the strategic interactions between firms.

The variable profit of developer $i$ in local market $m$ at period $t$ is

$$
\pi_{i m t}\left(\mathbf{a}_{m t}, \mathbf{p}_{m t}\right)=\left(p_{i m t}-c_{i m t}\right) M_{m t} s_{i m t}\left(\mathbf{a}_{m t}, p_{m t} ; \theta_{\mathbf{1}}\right)
$$

where $c_{i m t}$ is the marginal cost of an apartment offered by developer $i$, that is constant with respected to the quantity sold. Similarly to the mean utility, I specify the marginal cost as a function of apartment and condominium characteristics, as well as developer and year fixed effects, a market-specific linear trend and a shock that is product/firm specific:

$$
c_{i m t}=W_{i m t}^{\prime} \gamma+\omega_{i}+\omega_{m t}+\omega_{t}+\eta_{i m t}
$$

\footnotetext{
${ }^{4}$ Although a specification as a random coefficient logit would be more sophisticated, which allows for more demand heterogeneity, it would impose computational costs, given that, as we shall see in next Chapter, I need to compute the equilibrium price and period profit for every possible market configuration (i.e., not only for those states observed in the data). Furthermore, note that my geographic market definition is large enough to reduce correlations in consumers' preferences across markets. Similar assumptions are made in Aguirregabiria e Ho (2012).

${ }^{5}$ As pointed out in Berry (1994), it is important to distinguish between observed market shares and the market share function. Since mean utility levels contain the error or taste shocks, $\xi_{i m t}$, then conditional on the true values of mean utility and assuming a density for this term, the model should properly fit the data.
} 
As Glaeser, Gyourko e Saks (2005) point out, the marginal cost to build an additional apartment can be seen as the cost to build another floor and that developers with projects on larger plots can dilute the marginal cost by building more units in the development. For this reason, vector $W$ includes the number of apartments by floor, number of storeys, land plot size, along with the number of bathrooms, useful floor area and distance variables (to metro station and Downtown).

I assume that developers compete in prices in a Bertrand-Nash fashion. With some abuse of notation, the first order condition of Eq. 4.6 yields to:

$$
\mathbf{p}_{i m t}\left(\mathbf{a}_{m t} ; \theta_{\mathbf{1}}\right)=c_{i m t}-\frac{s_{i m t}}{\partial s_{i m t} / \partial p_{i m t}}
$$

Using some algebra in Eq. 4.5, I obtain the demand derivative in the denominator in Eq. 4.8, which leads us to the system of equilibrium price equations, for each firm in each market/period:

$$
\mathbf{p}_{i m t}\left(\mathbf{a}_{m t} ; \theta_{\mathbf{1}}\right)=c_{i m t}-\frac{1}{\alpha\left[1-s_{i m t}\left(\mathbf{a}_{m t}, p_{m t} ; \theta_{\mathbf{1}}\right)\right]}
$$

where $s_{i m t}$ is defined as in Eq. 4.5 .

\subsubsection{Fixed Cost Function}

If the developer chooses to enter in market $m$, it faces costs to build a development, which can be summed up in construction costs, advertising costs and financial/administrative costs. As we discussed before, the municipal land use regulation directly affects this cost structure, as it may limit the potential for land construction through zoning restrictions or by creating legal uncertainty due to delays in approvals, among other obligations that the government may require. Therefore, I model the fixed cost function as follows:

$$
F_{\text {imt }}=\delta_{0}+\delta_{1} \text { delay }_{i m t}+\delta_{2} L A N D_{i m t}+\varphi_{i}+\varphi_{t}
$$

delay is the amount of time between the developer's application and the issuance of the first license approving the project/development. $L A N D$ is a proxy for the value of the land. As seen in Section 2.2, this element constitutes an important barrier to entry to this activity. The constant $\delta_{0}$ captures operational costs that the firm has to pay independent of other costs. Regulations and costs of any other kind are summed up in this 
term. ${ }^{6}$ To capture the heterogeneity between developers' capacity or ability/experience in each market, I include a firm fixed-effect, $\varphi_{i}$. Finally, the regressions have a time fixed effect, $\varphi_{t}$, to control for macroeconomic effects, that are an important element from this industry (such as interest rate movements, inflation, unemployment in construction sector, etc.). I denote all the structural parameters of the cost function in the vector $\theta_{\mathbf{2}}=\left\{\delta_{0}, \delta_{1}, \delta_{2},\left\{\varphi_{i}\right\}_{i}^{N_{m}},\left\{\varphi_{t}\right\}_{t}^{T}\right\}$.

\footnotetext{
${ }^{6}$ I focus on the approval delay as the measure of municipal regulation. The reason to not include all other measures of regulation, as Zoning Fee or environmental compensation, is two-fold: i) the intercept already indicates the amount of this type of monetary cost; ii) to keep the model flexible enough.
} 


\section{Estimation Strategy}

My strategy relies on consistently estimating the mean utility parameters in $\theta_{\mathbf{1}}$ and solve for equilibrium prices of the static Bertrand-Nash competition. I then calculate the period profit for each developer in each local market for every possible market structure or states, i.e. not only for those that I observe in the data. These period profits flow back into the Entry Stage, in which I estimate the cost structural parameters in $\theta_{\mathbf{2}}$ that entrants face at the local market level.

This Chapter provides specific details on how I incorporate the findings of the Competition Stage into the Entry Stage and how I estimate the model. I use a Two-Step estimation procedure similar to most recent papers in the IO field. In particular, this Chapter draws on the works of Draganska, Mazzeo e Seim (2009) and Aguirregabiria e Ho (2012).

\subsection{Competition Stage}

To estimate $\boldsymbol{\theta}_{\mathbf{1}}$, I follow the traditional approach in Berry (1994), Berry, Levinsohn e Pakes (1995) and Nevo (2001). The multinomial logit implies that I have closed-form for the demand systems. Taking logs in Equation 4.5 leads us to a regression expression:

$$
\ln \left(s_{i m t}\right)-\ln \left(s_{0 m t}\right)=X_{i m t}^{\prime} \beta-\alpha p_{i m t}+\xi_{i}+\xi_{m t}+\xi_{t}+\xi_{i m t}
$$

so that $s_{0 m t}=1-\sum_{i^{\prime} \in \mathbf{N}_{m t}} s_{i^{\prime} m t}$ is the market share of the outside option.

After estimating $\hat{\theta_{1}}$ from 5.1, I back out marginal costs from the first-order condition in Eq. 4.9, using the observed prices and market shares. I then project these recovered marginal costs into some apartment characteristics and fixed effects, by estimating Eq. 4.7. Later, I compute the period profit in Eq. 4.6 using the predicted shares, the marginal cost estimates and the equilibrium prices, scaled up by the market size variable (population in each market/year).

\subsubsection{An example}

To illustrate my procedure, consider a hypothetical scenario when I have 2 firms (A and B) deciding to launch a residential development in a specific local market $m$ and year $t$. At the Competition Stage, I estimate $\hat{\theta_{1}}$ using Eq. 5.1 so that it flows into the mean utility for each specific product/firm $\left(\hat{V}_{i m t}\right)$. We have 4 possible market structures: 
$\left(a_{A m t}, a_{B m t}\right)=\{(0,0),(1,0),(0,1),(1,1)\}$. Then, I compute the predicted share for firm A in $m / t$ :

$$
\begin{gathered}
s_{A m t}\left((1,0), p_{A t} ; \hat{\theta}_{\mathbf{1}}\right)=\frac{e^{\hat{V}_{A m t}}}{1+\left(e^{\hat{V}_{A m t}}\right)} \\
s_{A m t}\left((1,1), p_{A t} ; \hat{\theta}_{\mathbf{1}}\right)=\frac{e^{\hat{V}_{A m t}}}{1+\left(e^{\hat{V}_{A m t}}+e^{\hat{V}_{B m t}}\right)} \\
s_{A m t}\left((0,0), p_{A t} ; \hat{\theta}_{\mathbf{1}}\right)=0=s_{A m t}\left((0,1), p_{A t} ; \hat{\theta}_{\mathbf{1}}\right)
\end{gathered}
$$

Now, consider only the $\{(1,1)\}$ scenario (when both firms enter). Thus, the equilibrium price for developer $\mathrm{A}$ under this configuration is:

$$
\mathbf{p}_{A m t}\left((1,1), p_{A t} ; \hat{\theta}_{\mathbf{1}}\right)=\hat{c}_{A m t}-\frac{1}{\hat{\alpha}\left[1-s_{A m t}((1,1), .)\right]}
$$

Therefore, from Eq. 4.6 I compute the period profit under this scenario:

$$
\left.\pi_{A m t}\left((1,1), \mathbf{p}_{m t}\right)=\left[\mathbf{p}_{A m t}((1,1), .)-\hat{c}_{A m t}\right) M_{m t} s_{A m t}((1,1), .)\right]
$$

Note that the number of equilibrium prices and period profits grow exponentially with the number of firms in the market. I shall discuss later some ways to reduce this dimensionality problem.

\subsection{Entry Stage}

The Bertrand-Nash assumption means that after entry, the apartment price is the strategic variable for developers. Since one firm does not know the payoff of other developer, due to the private profitability shock $\mathscr{E}_{i m t}$, it cannot predict their entry choices with certainty. Remember that the observed payoff relevant variables are $\left\{\mathbf{a}_{m t}, \mathbf{z}_{i m t}\right\}$. I denote the vector of state variables $\mathbf{w}_{i m t} \in W$ as a deterministic function of these payoff relevant variables in the original problem.

Therefore, at the beginning of each year $t$, developer $i$ has information about the state variables in $\mathbf{w}_{i m t}$, so it is optimal to enter the local market $m$ if its expected payoff of entering is as great as that of not entering, conditional on its beliefs $\sigma_{i}$ about other firms' decisions. I.e, 


$$
\begin{aligned}
\mathbf{V}_{i}^{\sigma}\left(a_{i m t}=1 ; \mathbf{w}_{i m t}, \mathscr{E}_{i m t}\right) \geq \mathbf{V}_{i}^{\sigma}\left(a_{i m t}=0 ; \mathbf{w}_{i m t}, \mathscr{E}_{i m t}\right) \quad & \\
\sum_{\mathbf{a}_{-i m t}} \sigma_{i m t}\left(\mathbf{w}_{i m t}\right)\left[\left(\mathbf{p}_{i m t}-\hat{c}_{i m t}\right) M_{m t} s_{i m t}\left(\mathbf{a}_{m t}, p_{m t} ; \hat{\theta_{1}}\right)+F_{i m t}\left(\mathbf{z}_{i m t}^{F C}, \theta_{\mathbf{2}}\right)\right]+ & \mathscr{E}_{i m t} \\
& \geq 0
\end{aligned}
$$

Note that the fixed cost function does not depend on actions' profile. Therefore, we can rewrite Eq. 5.3 as follows:

$$
\mathscr{E}_{i m t} \leq-\left[\tilde{\boldsymbol{\Pi}}_{i m t}^{\sigma}\left(\mathbf{a}_{m t}, \mathbf{p}_{m t} ; \hat{\theta_{\mathbf{1}}}\right)+F_{i m t}\left(\mathbf{z}_{i m t}^{F C}, \theta_{\mathbf{2}}\right)\right]
$$

where $\tilde{\boldsymbol{\Pi}}_{i m t}^{\sigma}\left(\mathbf{a}_{m t}, \mathbf{p}_{m t} ; \hat{\theta_{\mathbf{1}}}\right)=\sum_{\mathbf{a}_{-i m t}} \sigma_{i m t}\left(\mathbf{w}_{i m t}\right)\left[\left(\mathbf{p}_{i m t}-\hat{c}_{i m t}\right) M_{m t} s_{i m t}\left(\mathbf{a}_{m t}, p_{m t} ; \hat{\theta_{\mathbf{1}}}\right)\right]$, is the developer's expectation of variable profits using its own beliefs $\sigma$ on competitors' action profile.

Let $\mathcal{P}_{i m t}(\mathbf{w})=\left\{\operatorname{Prob}_{i m t}\left(\sigma_{i m t}\left(\mathbf{w}_{i m t}\right)=1\right)\right.$ : for every $i, m, t$, and $\left.\mathbf{w}_{i m t}=\mathbf{w} \in W\right\}$ be the vector of Conditional Choice Probabilities (CCPs) related to the best response strategy $\sigma_{i m t}$, one for each developer-market-year combination, in which $\operatorname{Prob}_{i m t}\left(\sigma_{i m t}\left(\mathbf{w}_{i m t}\right)\right)$ is the developer's entry probability given $\mathbf{w}_{i m t}=\mathbf{w}$.

Then, the best response probability is just the best response strategy integrated over the distribution of the private profitability shock, $\mathscr{E}_{i m t}$, which I assume to be i.i.d.. across firms. Similarly, a Bayesian Nash Equilibrium (BNE) in my model of real estate developers' competition is a vector of CCPs, $\mathcal{P}_{i m t}(\mathbf{w})$. Thus, from Eq. 5.4, we have that:

$$
\mathcal{P}_{i m t}(\mathbf{w})=\int \mathbb{1}\left\{\mathscr{E}_{i m t} \leq-\left[\tilde{\boldsymbol{\Pi}}_{i m t}^{\boldsymbol{\sigma}}\left(\mathbf{a}_{m t}, \mathbf{p}_{m t} ; \hat{\theta_{\mathbf{1}}}\right)+F_{i m t}\left(\mathbf{z}_{i m t}^{F C}, \theta_{\mathbf{2}}\right)\right]\right\} d \mathbf{G}_{\mathscr{E}}
$$

I assume that $\mathscr{E} \sim \mathbf{G}_{\mathscr{E}}$ is a Type-1 extreme value random variable, so that I have closed-form solution for the equilibrium:

$$
\mathcal{P}_{i m t}(\mathbf{w})=1-\exp \left\{-\exp \left\{-\left[\frac{\tilde{\boldsymbol{\Pi}}_{i m t}^{\sigma}\left(\mathbf{a}_{m t}, \mathbf{p}_{m t} ; \hat{\theta_{\mathbf{1}}}\right)+F_{i m t}\left(\mathbf{z}_{i m t}^{F C}, \theta_{\mathbf{2}}\right)}{\sigma_{\mathscr{E}}}\right]\right\}\right\}
$$

where $\sigma_{\mathscr{E}}$ is the dispersion parameter of the logit distribution. Following current IO literature and by exploiting the linearity-in-parameters in the payoff function, I invert Eq. 5.6 (see Hotz e Miller (1993)). Then we obtain the following system of moments:

$$
\mathcal{Y}\left(\mathbf{w}_{i m t} ; \sigma_{i m t}\right)-\mathcal{X}\left(\mathbf{w}_{i m t} ; \sigma_{i m t}\right) \Theta_{\text {im }}^{\prime}=0
$$


where

$$
\begin{gathered}
\mathcal{Y}\left(\mathbf{w}_{i m t} ; \sigma_{i m t}\right)=\ln \left[\ln \left(\frac{1}{1-\mathcal{P}_{i m t}(\mathbf{w})}\right)\right] \\
\mathcal{X}\left(\mathbf{w}_{i m t} ; \sigma_{i m t}\right)=-\left[\frac{\tilde{\boldsymbol{\Pi}}_{i m t}^{\sigma}\left(\mathbf{a}_{m t}, \mathbf{p}_{m t} ; \hat{\theta_{\mathbf{1}}}\right)+F_{i m t}\left(\mathbf{z}_{i m t}^{F C}, \theta_{\mathbf{2}}\right)}{\sigma_{\mathscr{E}}}\right]
\end{gathered}
$$

and $\boldsymbol{\Theta}_{\mathrm{im}}=\left\{\delta_{0}, \delta_{1}, \delta_{2},\{\varphi\}_{i}^{N_{m}},\{\varphi\}_{t}^{T}\right\}$ is the vector of structural cost parameters, $\theta_{\mathbf{2}}$, for each developer-market, as defined in Eq. 4.10.

The system of moments can also be seen as a fixed-point problem, so an equilibrium exists by the Brouwer's Theorem. However, it may not be unique in this class of games. Hence, similar to previous studies (such as Bajari et al. (2010), Pesendorfer e SchmidtDengler (2008)), I adopt a Two-Step procedure to solve and estimate the model. In a First Step, I assume that the data are generated by only one equilibrium, so that I can consistently estimate the beliefs $\left\{\sigma_{i m t}\left(\mathbf{w}_{i m t}\right)\right\}$ direct from the data. In particular, to support this unique equilibrium assumption, I estimate the model for each market separately. This is important in my application since, as seen in Section 2.2, there is a strong heterogeneity between markets, which means that the real estate activity is not the same in all markets. Thus, we clearly have different games being played, so that we may reach different equilibrium in each local market.

After I estimate the CCPs, $\left\{\hat{\sigma}_{i m t}\right\}$, using a flexible specification, I evaluate them in the vector $\mathcal{P}_{i m t}(\mathbf{w})$, conditional on state $\mathbf{w}_{i m t}=\mathbf{w} \in W$ and construct the analogue of Eq. 5.8, i.e $\hat{\mathcal{Y}}\left(\mathbf{w}_{i m t} ; \hat{\sigma}_{i m t}\right)$, which is $N_{m} T \times 1$. Similarly, together with the period profits computed at the Competition Stage for all actions' profile, I can build the analogue of Eq. 5.9, $\hat{\mathcal{X}}\left(\mathbf{w}_{i m t} ; \hat{\sigma}_{i m t}\right)$, which is $N_{m} T \times K_{\theta_{2}}$, where $K_{\theta_{2}}$ is the number of structural parameters to be estimated.

In the Second Step, I recover the cost structural parameters in $\boldsymbol{\Theta}_{\mathbf{i m}}$. For this, rewriting Eq. 5.7:

$$
\hat{\mathcal{Y}}\left(\mathbf{w}_{i m t} ; \hat{\sigma}_{i m t}\right)=\hat{\mathcal{X}}\left(\mathbf{w}_{i m t} ; \hat{\sigma}_{i m t}\right) \Theta_{\mathrm{im}}^{\prime}+\hat{\mathcal{U}}_{i m t}
$$

where,

$$
\hat{\mathcal{U}}_{i m t}=\left(\hat{\mathcal{Y}}\left(\mathbf{w}_{i m t} ; \hat{\sigma}_{i m t}\right)-\hat{\mathcal{X}}\left(\mathbf{w}_{i m t} ; \hat{\sigma}_{i m t}\right) \Theta_{\mathrm{im}}^{\prime}\right)-\left(\mathcal{Y}\left(\mathbf{w}_{i m t} ; \sigma_{i m t}\right)-\mathcal{X}\left(\mathbf{w}_{i m t} ; \sigma_{i m t}\right) \Theta_{\mathrm{im}}^{\prime}\right)
$$


I consistently estimate Eq. 5.10 using the OLS estimator, as in Sanches, Junior e Srisuma (2016b), who has proved the consistency and asymptotic properties for this estimator in games with linear-in-parameter payoffs.

In short, for each market separately, I find estimates for $\boldsymbol{\Theta}_{\mathrm{im}}$ as follows:

1. Estimate the Competition Stage: obtain $\hat{\theta_{\mathbf{1}}}$ and construct predicted shares, equilibrium prices and period profits in every possible configuration of $\mathbf{a}_{-\mathbf{i m t}}$, using Equations 4.5, 4.9 and 4.6, respectively.

2. Estimate the CCPs $\left\{\hat{\sigma}_{i m t}\right\}$ for the observed states.

3. For each state $\mathbf{w}_{\text {imt }}$ observed in the data, compute predicted entry probability, $\mathcal{P}_{\text {imt }}(\mathbf{w})$ in every possible market structure, as in Step 1.

4. Construct matrix $\mathcal{X}\left(\mathbf{w}_{i m t} ; \hat{\sigma}_{i m t}\right)$ using Eq. 5.9 and vector $\mathcal{Y}\left(\mathbf{w}_{i m t} ; \hat{\sigma}_{i m t}\right)$ using Eq. 5.8 .

5. Estimate the Entry Stage, regressing Equation 5.10.

\subsection{Dimensionality problem}

The solution and estimation of the Entry Stage requires us to "evaluate" expected payoffs over the space of the competitors actions' profile. For this reason I have defined equilibrium prices and, consequently, the period profits depending on all possible market configuration: $\mathbf{p}_{i m t}\left(a_{1 m t}, a_{2 m t}, \ldots, a_{N m t} ; \theta_{\mathbf{1}}\right)$. Therefore, to compute period profits, I need to solve a system of $2^{N_{m}-1}$ predicted shares and equilibrium prices. ${ }^{1}$ Given the number of developers in the data in each local market, this would be infeasible. ${ }^{2}$ I handle this computational cost by including some simplifying assumptions to reduce the dimensionality of the game and make its estimation tractable. First, for the Entry Stage, I assume that each local market has a pool of up to 20 potential firms deciding to launch a residential development. This choice is to ensure that this set of firms represents a large share of apartments launched in the local market over the period. Since most markets have more than 20 potential firms, I aggregate all other developers into one local firm (market specific). In addition, I compute the medians of observed state variables from all these other developers and assign them to that local firm.

Secondly, as defined in Section 4.2, I focus the analysis on single product firms in the Competition Stage. Thus, I am concerned about the "median apartment" launched

\footnotetext{
${ }^{1}$ There are $N_{m}$ potential entrants in each market and, given that I fixed payoff to be zero under $a_{i m t}=0$, I only need to solve for $a_{i m t}=1$.

${ }^{2}$ For example, a median market in my data has about 100 developers with at least one development launched during the period. This would lead to $\sim 1.27 \times 10^{30}$ profits to be computed for just one year.
} 
by each developer, in terms of characteristics that enter in my demand system. In the data, when a developer launches more than one residential development in the same market/year, I sum the total of apartments of each project and calculate the median of the characteristics of the units and the condominium. Hence, for the possible counterfactual market structure (that I do not observe in the data), I compute the features of the "median development/apartment", at the firm-market level. 


\section{Results}

This Chapter presents the results for the Competition Stage and the Entry Stage, following the steps described in Section 5.2. Important to note, the demand estimates consider all developers in the data, while the CCP and the structural estimation look at the pool of 20 entrants, as I stated before. The identities of these developers can be found in Appendix B.

\subsection{Demand Estimation}

I estimate the demand system using Eq. 5.1 for all firms. We expect the unobservable term $\xi_{\text {imt }}$ to be correlated with prices, which is problematic since this term will be the econometric error. The endogeneity appears because this term is assumed to be observed by both consumers and firms: for instance, apartments with higher $\xi_{\text {imt }}$ are more valued by consumers and therefore, developers recognize this fact and price them higher.

By adding firm fixed effects I try to control for "quality" or "style" of the apartment, which are intrinsically difficult to measure but are frequent determinants of demand. I also include year dummies and linear trend for each local market to account for common demand shocks for all apartments and for those in the same region. Finally, instrument variables are a common way to deal with this problem. Berry, Levinsohn e Pakes (1995) were the first to note that characteristics of the competitors' products are appropriate instruments because they are excluded from the utility specification in Eq. 4.5 , since $X_{-i}$ does not influence utility $V_{i m t}$ and they are correlated with prices via markups in the first-order condition in Eq. 4.8. In other words, one might expect the closer two products are in product space, more similar they are in the minds of consumers.

Thus, I use the following set of characteristics of competitors' apartments in the same market and year as instruments for price: number of bedrooms and garages, useful floor area of the apartment, number of stories in the building, number of apartments per floor, land lot size, number of buildings in the condominium. Moreover, it is worth mentioning that such characteristics are set in the Permit request by the developers. As highlighted in Section 2.1, at this stage, that happens before the demand shocks at year $t$, firms must already present a detailed project with architectural design of the development and residences. This time-to-build implies that the characteristics of apartments from other developers are independent of the unobserved demand term, $\xi_{i m t}$. Aguirregabiria e Ho (2012) and Sweeting (2013) consider similar assumption. 
For a better identification, I consider only 2 and 3 bedroom apartments. ${ }^{1}$ This accounts for $70 \%$ of apartments in the data. Table 8 presents the estimates.

Table 8 - Demand System Estimation

\begin{tabular}{|c|c|c|c|c|}
\hline \multirow[t]{2}{*}{ Variable } & \multicolumn{3}{|c|}{ OLS } & \multirow{2}{*}{$\frac{\text { IV }}{\text { (iv) }}$} \\
\hline & (i) & (ii) & (iii) & \\
\hline Price (in $\mathrm{R} \$ 10 \mathrm{~K}$ ) [Parameter $\alpha$ ] & $\begin{array}{c}-0.00209^{* * *} \\
(0.001)\end{array}$ & $\begin{array}{c}-0.00498^{* * *} \\
(0.001)\end{array}$ & $\begin{array}{c}-0.00635^{* * *} \\
(0.001)\end{array}$ & $\begin{array}{c}-0.0330^{* * *} \\
(0.010)\end{array}$ \\
\hline \multicolumn{5}{|l|}{ Apartment Characteristics } \\
\hline Bedrooms - bin1 $[2.25,2.5]$ & $\begin{array}{c}0.415^{* * *} \\
(0.041)\end{array}$ & $\begin{array}{c}0.280^{* * *} \\
(0.053)\end{array}$ & $\begin{array}{c}0.299 * * * \\
(0.052)\end{array}$ & $\begin{array}{c}0.322^{* * * *} \\
(0.049)\end{array}$ \\
\hline Bedrooms - bin2 $[2.75,3]$ & $\begin{array}{c}0.132 * * * \\
(0.045)\end{array}$ & $\begin{array}{l}0.0848 \\
(0.063)\end{array}$ & $\begin{array}{l}0.120^{*} \\
(0.064)\end{array}$ & $\begin{array}{l}0.0838 \\
(0.076)\end{array}$ \\
\hline Garages - bin1 $[1.25,1.5]$ & $\begin{array}{l}0.105^{* *} \\
(0.046)\end{array}$ & $\begin{array}{l}0.0569 \\
(0.063)\end{array}$ & $\begin{array}{l}0.0439 \\
(0.059)\end{array}$ & $\begin{array}{c}0.143^{* *} \\
(0.070)\end{array}$ \\
\hline Garages - bin2 $[1.75,2]$ & $\begin{array}{c}-0.148^{* * *} \\
(0.046)\end{array}$ & $\begin{array}{c}-0.168^{* *} \\
(0.068)\end{array}$ & $\begin{array}{c}-0.198^{* * * *} \\
(0.067)\end{array}$ & $\begin{array}{l}0.0268 \\
(0.112)\end{array}$ \\
\hline Garages - bin $3[>2]$ & $\begin{array}{c}-0.272^{* * *} \\
(0.080)\end{array}$ & $\begin{array}{l}-0.178 \\
(0.118)\end{array}$ & $\begin{array}{l}-0.175 \\
(0.115)\end{array}$ & $\begin{array}{l}1.101^{* *} \\
(0.517)\end{array}$ \\
\hline Useful area $\left[55 \mathrm{~m}^{2}\right.$ to $\left.67 \mathrm{~m}^{2}\right]$ & $\begin{array}{c}-0.121^{* * *} \\
(0.040)\end{array}$ & $\begin{array}{c}-0.124^{* *} \\
(0.056)\end{array}$ & $\begin{array}{c}-0.138^{* *} \\
(0.056)\end{array}$ & $\begin{array}{c}-0.00372 \\
(0.069)\end{array}$ \\
\hline Useful area $\left[67 \mathrm{~m}^{2}\right.$ to $\left.89 \mathrm{~m}^{2}\right]$ & $\begin{array}{c}-0.166^{* * *} \\
(0.059)\end{array}$ & $\begin{array}{l}-0.123 \\
(0.083)\end{array}$ & $\begin{array}{l}-0.139^{*} \\
(0.083)\end{array}$ & $\begin{array}{l}0.187 \\
(0.147)\end{array}$ \\
\hline Useful area $\left[>89 \mathrm{~m}^{2}\right]$ & $\begin{array}{c}-0.368^{* * * *} \\
(0.072)\end{array}$ & $\begin{array}{c}-0.353^{* * *} \\
(0.105)\end{array}$ & $\begin{array}{c}-0.360^{* * *} \\
(0.104)\end{array}$ & $\begin{array}{l}0.408 \\
(0.316)\end{array}$ \\
\hline \multicolumn{5}{|l|}{ Condominium Characteristics } \\
\hline Buildings & $\begin{array}{c}0.199^{* * *} \\
(0.012)\end{array}$ & $\begin{array}{c}0.131 * * * \\
(0.016)\end{array}$ & $\begin{array}{c}0.133^{* * *} \\
(0.015)\end{array}$ & $\begin{array}{c}0.138^{* * *} \\
(0.015)\end{array}$ \\
\hline Elevators & $\begin{array}{c}0.221^{* * *} \\
(0.020)\end{array}$ & $\begin{array}{c}0.182^{* * *} \\
(0.026)\end{array}$ & $\begin{array}{c}0.185^{* * *} \\
(0.025)\end{array}$ & $\begin{array}{c}0.162^{* * * *} \\
(0.027)\end{array}$ \\
\hline Units/Floor & $\begin{array}{c}0.0829^{* * *} \\
(0.010)\end{array}$ & $\begin{array}{c}0.0496^{* * *} \\
(0.012)\end{array}$ & $\begin{array}{c}0.0497^{* * *} \\
(0.013)\end{array}$ & $\begin{array}{c}0.0380^{* * * *} \\
(0.013)\end{array}$ \\
\hline Storeys & $\begin{array}{c}0.0622^{* * *} \\
(0.003)\end{array}$ & $\begin{array}{c}0.0464^{* * *} \\
(0.004)\end{array}$ & $\begin{array}{c}0.0440^{* * *} \\
(0.004)\end{array}$ & $\begin{array}{c}0.0413^{* * * *} \\
(0.005)\end{array}$ \\
\hline Distance to metro & $\begin{array}{l}0.0205 \\
(0.014)\end{array}$ & $\begin{array}{c}-0.00734 \\
(0.021)\end{array}$ & $\begin{array}{l}0.0217 \\
(0.024)\end{array}$ & $\begin{array}{c}0.0624^{* *} \\
(0.029)\end{array}$ \\
\hline Distance to park & $\begin{array}{c}0.0346^{* * *} \\
(0.009)\end{array}$ & $\begin{array}{c}0.0369^{* * *} \\
(0.014)\end{array}$ & $\begin{array}{l}0.0121 \\
(0.014)\end{array}$ & $\begin{array}{l}-0.0220 \\
(0.020)\end{array}$ \\
\hline Distance to Downtown ${ }^{(i)}$ (Sé Square) & $\begin{array}{c}-0.00232 \\
(0.009)\end{array}$ & $\begin{array}{c}-0.00203 \\
(0.014)\end{array}$ & $\begin{array}{c}-0.00701 \\
(0.021)\end{array}$ & $\begin{array}{l}0.0285 \\
(0.025)\end{array}$ \\
\hline Distance to Downtown ${ }^{(i i)}$ (Paulista Avenue) & $\begin{array}{l}0.00995 \\
(0.009)\end{array}$ & $\begin{array}{l}0.00475 \\
(0.014)\end{array}$ & $\begin{array}{l}0.0157 \\
(0.022)\end{array}$ & $\begin{array}{r}-0.0539 \\
(0.034)\end{array}$ \\
\hline Year dummies & Yes & Yes & Yes & Yes \\
\hline Developer Fixed Effect & No & Yes & Yes & Yes \\
\hline Local market linear trend & No & No & Yes & Yes \\
\hline $\begin{array}{l}\text { Observations } \\
R^{2}\end{array}$ & 1,956 & 1,956 & 1,906 & 1,906 \\
\hline F-stat & & & & 102.3 \\
\hline
\end{tabular}

Columns range from a less controlled estimate to a more controlled estimate (which includes fixed effects and local linear trend). Given a strong variation in the apartment characteristics, I discretize them and include the dummies of each bin instead of their

\footnotetext{
${ }^{1}$ The data show a very skewed distribution of characteristics for one-bedroom apartments along with significant variation in price. One reasonable explanation is that one-bedroom apartments can be either apartments for low-income consumers or for high-income consumers (e.g., flats or studios). Likewise, apartments with more than 3 bedrooms can be set up in a luxury class. In the data, an apartment of this type has an average price of $\mathrm{R} \$ 1.7$ million.
} 
levels. ${ }^{2}$ As expected, prices negatively affect consumers' utility. The average implied own elasticity is -1.462 . Columns (iii) and (iv) expose the endogeneity in OLS estimation: IV estimates for prices are substantially smaller. We should expect this result because the bias in the econometric error are normally an upwards attenuation bias in such case.

Most of characteristics coefficients have the expected signal, although some of them are not statistically significant. By dividing the estimates of each characteristic of the apartment by the price coefficient, we have estimates for the correspondent willingnessto-pay. Consumers can pay about $\mathrm{R} \$ 330.000$ more for apartments with more than 2 garages. In general, it seems that the features of the condo play a more important role for consumers than the features of the apartment itself. Larger developments and taller buildings are more valued by consumers. Also, there is a preference for living closer to Paulista Avenue and farther away from the Sé Square, although these effects are not statistically significant. However, the estimates for the variable of distance to metro station are somewhat implausible.

\subsection{Marginal Cost Estimates}

I can recover the marginal costs by exploiting the Bertrand-Nash assumption, which leads us to Eq. 4.9. Then, I use these estimates as the dependent variable of Eq. 4.7 to measure the impacts of some characteristics of the apartment and the developments on marginal costs. Table 9 presents the estimates. As in the demand system estimation, I include year and firm fixed effects as well as a local market linear trend. The firm fixed effect is important in this regression as it captures "ability" to build or develop projects which may vary by firm size. I chose to include bathrooms and useful floor area as apartment characteristics because these features are more cost-related than number of bedrooms or garages.

Ceteris paribus, an apartment with more than $89 \mathrm{~m}^{2}$ implies that the marginal cost goes up by $\mathrm{R} \$ 335.000$. Also, developers can reduce the marginal cost per apartment by $\mathrm{R} \$ 2.600$ and $\mathrm{R} \$ 4.500$ if the building has an additional floor and an additional apartment per floor, respectively. Therefore, although I do not find a robust and statistically significant effect on development-related variables, it seems that larger projects are associated with lower marginal costs. This is plausible because developers are able to mitigate the overall cost by building more units in the same area.

\footnotetext{
${ }^{2}$ Estimates for the characteristics of the apartment should be interpreted considering a 2 bedroom apartment, with $50 \mathrm{~m}^{2}$ of useful floor area and up to one garage.
} 
Table 9 - Marginal Cost Estimation

\begin{tabular}{|c|c|}
\hline Variable & $c_{i m t}$ \\
\hline Bathrooms - bin1 $[1,2]$ & $\begin{array}{l}1.701 \\
(1.435)\end{array}$ \\
\hline Bathrooms - bin2 $[2,4]$ & $\begin{array}{c}39.05^{* * * *} \\
(5.406)\end{array}$ \\
\hline Useful area $\left[55 \mathrm{~m}^{2}\right.$ to $\left.67 \mathrm{~m}^{2}\right]$ & $\begin{array}{c}4.057^{* * *} \\
(1.393)\end{array}$ \\
\hline Useful area $\left[67 \mathrm{~m}^{2}\right.$ to $\left.89 \mathrm{~m}^{2}\right]$ & $\begin{array}{c}14.09 * * * \\
(1.761)\end{array}$ \\
\hline Useful area $\left[>89 \mathrm{~m}^{2}\right]$ & $\begin{array}{c}33.50^{* * *} \\
(2.676)\end{array}$ \\
\hline Units/Floor & $\begin{array}{l}-0.450 \\
(0.423)\end{array}$ \\
\hline Storeys & $\begin{array}{c}-0.261^{*} \\
(0.146)\end{array}$ \\
\hline Land Lot Size & $\begin{array}{c}-0.000207 \\
(0.000)\end{array}$ \\
\hline Distance to metro & $\begin{array}{c}0.924 \\
(0.819)\end{array}$ \\
\hline Distance to Downtown $^{(i)}$ (Sé Square) & $\begin{array}{c}1.234^{* *} \\
(0.617)\end{array}$ \\
\hline Distance to Downtown ${ }^{(i i)}$ (Paulista Avenue) & $\begin{array}{c}-2.625^{* * *} \\
(0.659)\end{array}$ \\
\hline Year dummies & Yes \\
\hline Developer Fixed Effect & Yes \\
\hline Local market linear trend & Yes \\
\hline Observations & 1,956 \\
\hline$R^{2}$ & 0.866 \\
\hline
\end{tabular}

\subsection{Fit of the Demand Model}

From now on, I consider only the potential pool of 20 entrants in each market. With the estimates for demand parameters, I compute the mean utility and the predicted share for each market configuration, using Eq. 4.5. The demand model plays an important role in this stage because it predicts market shares for the settings not observed in the data. Figure 8 shows that the simulated model does a reasonable matching to the distribution of observed market-year share. The correlation between the share predicted by the model and the share observed in the data for the 3 largest markets (in number of developments) is 0.33 and it is statistically significant at any standard significance level.

The Competition Stage is concluded by the computation of the period profits using the Bertrand-Nash assumption, i.e. more explicitly, Eq. 4.6. 
Figure 8 - Distribution of Firm-Market-Year Share

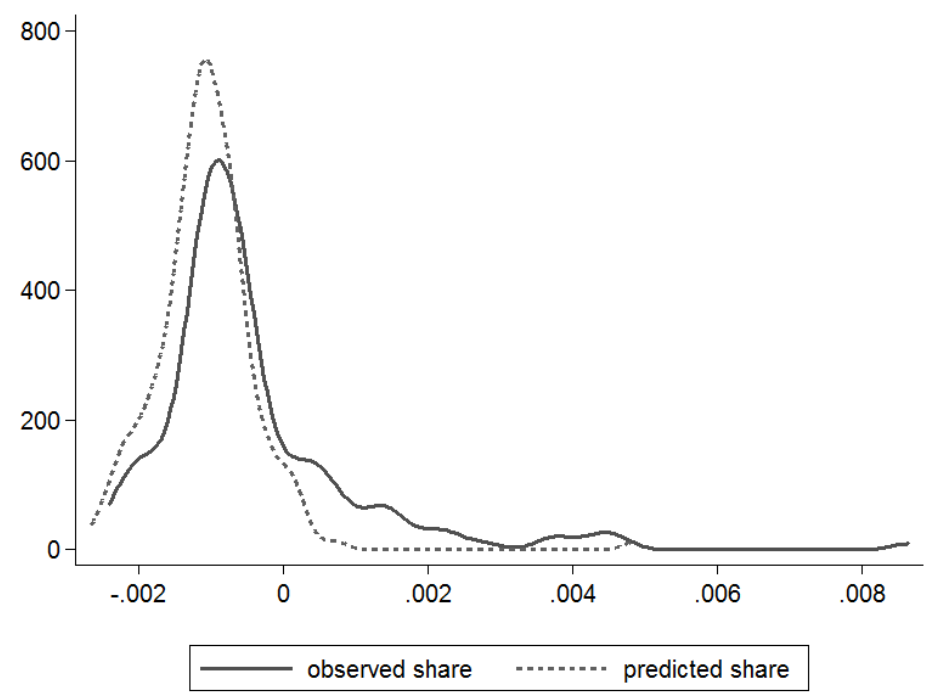

Note: Data (solid line), Model Prediction (dashed line).

Kernel density for Top 3 markets: Lapa, Pinheiros e Vila Mariana. Horizontal axis is scaled by mean observed share of each market.

\subsection{Conditional Choice Probabilities}

The CCPs are the equilibrium beliefs that I observe in the data. The Two-Step procedure of estimating the entry game relies on having consistent estimates for these beliefs, which can be done "outside" the structural estimation. Ideally, I should not impose any structure on these beliefs and estimate them using a non-parametric approach. However, given the size of the state space, this is a non-trivial solution. Most studies deal with this by assuming a semi or a full-parametric specification. I estimate the CCPs using the following parametric function:

$$
\begin{array}{r}
\operatorname{Prob}\left(a_{i m t}=1 \mid \mathbf{w}_{i m t} ; \phi, \rho\right)=\Phi\left[\phi_{0}+\phi_{1} a_{i m}^{t-1}+\phi_{2} n_{-i m}^{t-1}+\phi_{3} A P A R T_{-i m}^{t-1}\right. \\
\left.+\phi_{i m}+\phi_{t}+\rho \mathbf{Z}_{i m t}^{\text {cost }}\right]
\end{array}
$$

The dependent variable is the binary action of developer $i$ in market $m$ at year $t$ : it assumes 1 if developer $i$ launched a residential project in that market/year and zero otherwise. The equation above regress this decision on state variables. Following the notation used in Chapter $5, \mathbf{w}_{i m t}=\left\{a_{i m}^{t-1}, n_{-i m}^{t-1}, A P A R T_{-i m}^{t-1}, \mathbf{Z}_{i m t}^{\text {cost }}\right\}$, where $a_{i m}^{t-1}$ is the developer's decision in the same market at previous year, $n_{-i m}^{t-1}=\sum_{k \neq i}^{N_{m}} a_{k m}^{t-1}$ is the number of $i$ 's competitors in the local market at the previous year, $A P A R T_{-i m}^{t-1}$ is the total of apartments launched by $i$ 's competitors in the local market at the previous year ${ }^{3}$ and

\footnotetext{
${ }^{3}$ Note that $A P A R T_{-i m}^{t-1}$ depends on the competitors' actions profile.
} 
$\mathbf{Z}_{\text {imt }}^{\text {cost }}=\left\{\right.$ delay, LAND, ZONE, $\left.Z^{\text {build }}\right\}$ is the fixed-cost relevant variables defined in Eq. 4.10 along with the amount paid of Zoning Fee $(Z O N E)$. Vector $Z^{\text {build }}$ includes measures for construction costs: material cost and demolition in the lot. From Section 2.1, when a developer decides to launch a residential building, it already knows the variables in vector $\mathbf{Z}_{\text {imt }}^{\text {cost }}$. Hence, they are relevant in the firm's decision-making process and, therefore, I include them in the state vector. $\Phi$ denotes the logistic distribution and $\{\phi, \rho\}$ are the vectors of parameters to be estimated.

To account for unobserved firm heterogeneity, I include the term $\phi_{i m}$, which is firm-market specific. To construct $\phi_{i m}$, I follow the same procedure in Sanches, Junior e Srisuma (2016a). ${ }^{4}$ Firstly, I estimate Eq. 6.1 using a linear probability estimator with developer fixed effects and recover the estimates for these fixed effects. Then, I include these estimates as an explanatory variable in the logit function. Other parametric ways to address unobserved heterogeneity into the CCPs can be found in Collard-Wexler (2013) and $\operatorname{Lin}(2015) .^{5}$

As mentioned before, to reduce the dimensionality of vector $\mathbf{w}_{\text {imt }} \in W$, I estimate the CCPs and the structural model using a fixed set of potential entrants equal to 20 firms in each local market. In addition, for brevity, I present the results for the top 10 markets I have in the data. These selected markets describe the most significant aspects of the real estate activity in the city of São Paulo. Together, they account for about $75 \%$ of the total potential gross revenue and apartments launched from 2000 to 2013.

The CCPs estimates for each market separately are shown in Table 10. The columns range from the market with the most intense activity (Vila Mariana) to the lowest activity (Aricanduva), among the 10 largest markets. In view of space, I only present the most relevant coefficients. All estimates include year fixed effects.

There are heterogeneous effects across markets. To capture competition, in most markets the number of apartments launched by competitors is a better measure than the number of competitors. The more apartments $i$ 's competitors launched in the previous year, the lower the likelihood of $i$ launching a project in the same market in the present. This business-stealing effect is even stronger where real estate activity is more intense (columns from left to right). On the other hand, estimates seem to indicate that some markets, such as Pinheiros, can accommodate more developers, while in others (Ipiranga or Santana, for example) an additional firm has a strong and negative effect on the developer's decision.

\footnotetext{
${ }^{4}$ Discrete choice models, such as probit and logit, present some draw backs to include linear fixed effects. This theoretical issue dates from the incidental parameter problem, when the number of periods is limited compared to the number of observations in the estimation. For a more in-depth discussion on this issue, see Heckman (1981).

${ }^{5}$ For theoretical results and other insights on the problem of unobserved heterogeneity in the estimation of games see Arcidiacono e Miller (2011).
} 
Table 10 - First Step - Logit CCPs Estimates

\begin{tabular}{|c|c|c|c|c|c|c|c|c|c|c|}
\hline \multirow[b]{2}{*}{ Variables } & \multicolumn{10}{|l|}{ Local Markets } \\
\hline & Vila Mariana & Pinheiros & Lapa & Mooca & $\begin{array}{l}\text { Campo } \\
\text { Limpo }\end{array}$ & Ipiranga & Sé & Butantã & $\begin{array}{l}\text { Santana/ } \\
\text { Tucuruvi }\end{array}$ & Aricanduva \\
\hline \# competitors ${ }_{t-1}$ & $\begin{array}{l}-9.021 \\
(6.293)\end{array}$ & $\begin{array}{c}2.410^{* *} \\
(0.989)\end{array}$ & $\begin{array}{c}0.664 \\
(0.600)\end{array}$ & $\begin{array}{c}0.610 \\
(0.543)\end{array}$ & $\begin{array}{c}0.850 \\
(0.990)\end{array}$ & $\begin{array}{l}-72.87^{* *} \\
(37.041)\end{array}$ & $\begin{array}{l}1.811 \\
(1.455)\end{array}$ & $\begin{array}{l}-0.644 \\
(0.706)\end{array}$ & $\begin{array}{c}-4.946^{* *} \\
(2.214)\end{array}$ & $\begin{array}{l}-1.931 \\
(3.158)\end{array}$ \\
\hline \# apartments by competitors ${ }_{t-1}$ & $\begin{array}{c}-0.00930^{* * *} \\
(0.004)\end{array}$ & $\begin{array}{c}-0.00783^{* *} \\
(0.003)\end{array}$ & $\begin{array}{c}-0.00476^{* *} \\
(0.002)\end{array}$ & $\begin{array}{c}-0.00340^{*} \\
(0.002)\end{array}$ & $\begin{array}{c}-0.00155 \\
(0.001)\end{array}$ & $\begin{array}{c}-0.00321 \\
(0.002)\end{array}$ & $\begin{array}{c}-0.00296 \\
(0.002)\end{array}$ & $\begin{array}{c}2.51 \mathrm{e}-05 \\
(0.002)\end{array}$ & $\begin{array}{c}-0.00356 \\
(0.004)\end{array}$ & $\begin{array}{c}-0.000698 \\
(0.007)\end{array}$ \\
\hline delay & $\begin{array}{c}0.128^{* * *} \\
(0.039)\end{array}$ & $\begin{array}{l}0.0998 \\
(0.065)\end{array}$ & $\begin{array}{l}0.0622^{*} \\
(0.036)\end{array}$ & $\begin{array}{l}0.0468 \\
(0.033)\end{array}$ & $\begin{array}{l}0.188^{* *} \\
(0.077)\end{array}$ & $\begin{array}{c}0.116^{* * *} \\
(0.029)\end{array}$ & $\begin{array}{r}-0.0179 \\
(0.045)\end{array}$ & $\begin{array}{l}0.0384 \\
(0.026)\end{array}$ & $\begin{array}{c}0.118^{* * * *} \\
(0.040)\end{array}$ & $\begin{array}{c}0.120^{* * *} \\
(0.037)\end{array}$ \\
\hline$L A N D$ & $\begin{array}{l}0.00785^{* * *} \\
\quad(0.003)\end{array}$ & $\begin{array}{c}0.00127^{*} \\
(0.001)\end{array}$ & $\begin{array}{c}0.000541 \\
(0.001)\end{array}$ & $\begin{array}{c}0.00133 \\
(0.001)\end{array}$ & $\begin{array}{c}0.00127^{*} \\
(0.001)\end{array}$ & $\begin{array}{c}0.000296 \\
(0.001)\end{array}$ & $\begin{array}{l}0.00150^{* * *} \\
(0.000)\end{array}$ & $\begin{array}{c}0.00161^{*} \\
(0.001)\end{array}$ & $\begin{array}{l}0.00778^{* * *} \\
(0.003)\end{array}$ & $\begin{array}{l}0.00279 \\
(0.004)\end{array}$ \\
\hline$Z O N E$ & $\begin{array}{c}-0.0617^{* * *} \\
(0.023)\end{array}$ & $\begin{array}{l}0.00899 \\
(0.017)\end{array}$ & $\begin{array}{c}-0.00321 \\
(0.005)\end{array}$ & $\begin{array}{c}-0.00192 \\
(0.003)\end{array}$ & $\begin{array}{r}-0.0157 \\
(0.012)\end{array}$ & $\begin{array}{l}0.0126 \\
(0.009)\end{array}$ & $\begin{array}{c}-0.000599 \\
(0.005)\end{array}$ & $\begin{array}{c}0.0158^{* *} \\
(0.008)\end{array}$ & $\begin{array}{r}-0.0296 \\
(0.042)\end{array}$ & $\begin{array}{l}0.0144 \\
(0.010)\end{array}$ \\
\hline Developer/Market FE $\left(\phi_{i m}\right)$ & $\begin{array}{c}8.337^{* * *} \\
(1.621)\end{array}$ & $\begin{array}{c}7.399^{* * *} \\
(1.338)\end{array}$ & $\begin{array}{c}7.744^{* * * *} \\
(1.266)\end{array}$ & $\begin{array}{c}6.663^{* * *} \\
(1.189)\end{array}$ & $\begin{array}{c}6.808^{* * *} \\
(1.129)\end{array}$ & $\begin{array}{c}7.229^{* * *} \\
(1.067)\end{array}$ & $\begin{array}{c}7.187^{* * * *} \\
(1.217)\end{array}$ & $\begin{array}{c}7.617^{* * *} \\
(1.514)\end{array}$ & $\begin{array}{c}13.01^{* * *} \\
(2.766)\end{array}$ & $\begin{array}{c}7.389^{* * *} \\
(1.515)\end{array}$ \\
\hline Population & $\begin{array}{l}-0.105 \\
(0.541)\end{array}$ & $\begin{array}{l}-0.603 \\
(1.275) \\
\end{array}$ & $\begin{array}{l}-0.138 \\
(0.275) \\
\end{array}$ & $\begin{array}{c}-0.252 \\
(0.304) \\
\end{array}$ & $\begin{array}{c}0.103 \\
(0.110) \\
\end{array}$ & $\begin{array}{c}-2.205^{* *} \\
(0.896) \\
\end{array}$ & $\begin{array}{l}-0.198 \\
(0.606) \\
\end{array}$ & $\begin{array}{c}-0.530^{* *} \\
(0.221)\end{array}$ & $\begin{array}{c}-10.93^{* *} \\
(5.347)\end{array}$ & $\begin{array}{c}7.068 \\
(7.423) \\
\end{array}$ \\
\hline Observations & 260 & 260 & 260 & 260 & 260 & 260 & 260 & 260 & 260 & 260 \\
\hline
\end{tabular}

As expected, since the approval delay is performed earlier, it has a positive effect on the probability of launching the development. Also, the heterogeneous developer-market effect constitutes an essential element in determining the entry probabilities of developers. This component incorporates various particularities of the developer's activity in that specific market, such as "previous experiences" and more knowledge about the region's consumer profile. In addition, the Pseudo- $\mathrm{R}^{2}$ of the logit estimates (about 0.38) also indicates a plausible prediction of the model. Yet, a significant part of entering the market remains quite random.

\subsection{Structural Parameters}

I use the coefficients in Table 10 to calculate the conditional choice probability of reaching each possible state through the simulation of the state variables in vector $\mathbf{w}_{\text {imt }}$ that depend on the actions of other firms, i.e. $\left\{n_{-i m}^{t-1}, A P A R T_{-i m}^{t-1}\right\}$. By doing so and along with the period profit computed under each possible market configuration, I construct the sample analogues of Eq. 5.8 and Eq. 5.9. Table 11 reports the point estimates for structural parameters of vector $\theta_{\mathbf{2}}$. I calculate the standard errors by block bootstrapping the CCPs 50 times. For all markets, I include the developer and year fixed effects. For brevity, I omit them. ${ }^{6}$

The approval delay has a consistent negative effect on the developers' payoff across markets. The fixed cost only to be active in the local market, regardless of other cost, is large and negative, independent of the market. By including developer and year fixed-effects in all estimations, the results are not capturing the effects caused solely by unobserved heterogeneity in developers characteristics invariant over time, or unobserved

${ }^{6}$ There are 31 fixed effects in each regression: 20 developers and 13 years. I drop one of the year fixed-effect and one firm fixed effect to avoid perfect colinearity in the estimation. 
Table 11 - Structural Parameters (Point Estimates)

\begin{tabular}{|c|c|c|c|c|c|c|c|c|c|c|}
\hline \multirow[b]{2}{*}{ Variables } & \multicolumn{10}{|c|}{ Local Markets } \\
\hline & $\begin{array}{c}\text { Vila } \\
\text { Mariana }\end{array}$ & Pinheiros & Lapa & Mooca & $\begin{array}{l}\text { Campo } \\
\text { Limpo }\end{array}$ & Ipiranga & $\mathrm{Se}$ & Butanta & $\begin{array}{l}\text { Santana/ } \\
\text { Tucuruvi }\end{array}$ & Aricanduva \\
\hline delay & $\begin{array}{c}-0.0616 \\
{[0.02]}\end{array}$ & $\begin{array}{c}-0.0622 \\
{[0.04]}\end{array}$ & $\begin{array}{c}-0.0324 \\
{[0.03]}\end{array}$ & $\begin{array}{c}-0.0326 \\
{[0.05]}\end{array}$ & $\begin{array}{c}-0.0799 \\
{[0.03]}\end{array}$ & $\begin{array}{c}-0.0620 \\
{[0.02]}\end{array}$ & $\begin{array}{c}0.0173 \\
{[0.06]}\end{array}$ & $\begin{array}{c}-0.0312 \\
{[0.02]}\end{array}$ & $\begin{array}{c}-0.0660 \\
{[0.09]}\end{array}$ & $\begin{array}{c}-0.0866 \\
{[0.03]}\end{array}$ \\
\hline$L A N D$ & $\begin{array}{c}-0.0030 \\
{[0.00]}\end{array}$ & $\begin{array}{c}-0.0004 \\
{[0.00]}\end{array}$ & $\begin{array}{c}-0.0005 \\
{[0.00]}\end{array}$ & $\begin{array}{c}-0.0003 \\
{[0.00]}\end{array}$ & $\begin{array}{c}-0.0002 \\
{[0.00]}\end{array}$ & $\begin{array}{c}-0.0009 \\
{[0.00]}\end{array}$ & $\begin{array}{c}-0.0010 \\
{[0.00]}\end{array}$ & $\begin{array}{c}-0.0006 \\
{[0.00]}\end{array}$ & $\begin{array}{c}-0.0040 \\
{[0.00]}\end{array}$ & $\begin{array}{c}-0.0032 \\
{[0.00]}\end{array}$ \\
\hline $\begin{array}{l}\text { Operational Costs } \\
\text { (Intercept) }\end{array}$ & $\begin{array}{c}-3.9277 \\
{[1.08]}\end{array}$ & $\begin{array}{c}-3.1215 \\
{[0.68]}\end{array}$ & $\begin{array}{c}-1.0076 \\
{[0.61]}\end{array}$ & $\begin{array}{c}-4.5775 \\
{[1.13]}\end{array}$ & $\begin{array}{c}-4.7133 \\
{[1.75]}\end{array}$ & $\begin{array}{c}-1.1657 \\
{[1.14]}\end{array}$ & $\begin{array}{c}-3.6002 \\
{[1.26]}\end{array}$ & $\begin{array}{c}-3.9526 \\
{[1.37]}\end{array}$ & $\begin{array}{c}-3.7399 \\
{[2.62]}\end{array}$ & $\begin{array}{c}-3.4077 \\
{[1.12]}\end{array}$ \\
\hline Year FE & Yes & Yes & Yes & Yes & Yes & Yes & Yes & Yes & Yes & Yes \\
\hline Developer/Market FE & Yes & Yes & Yes & Yes & Yes & Yes & Yes & Yes & Yes & Yes \\
\hline Observations & $\overline{2260}$ & 260 & 260 & 260 & 260 & 260 & 260 & 260 & 260 & 260 \\
\hline
\end{tabular}

Note: Standard-errors were calculated from 50 block bootstraps of beliefs (CCPs) and are shown in brackets. The coefficients are measured in units of standard deviations of the iid profitability shock.

characteristics of the particular year (such as macroeconomic effects). Qualitatively, the estimates here are coherent with the usual results found in the literature on the effects of land use regulation. I also estimated another version of these regressions, including an entry cost term (specifically, entry $=\left(1-a_{i m}^{t-1}\right)$ ). This term was not statistically significant in any local market, implying that there are no other sunk costs in this activity, which is not being captured by the variables in Table 11. In addition, this also serves to validate my static approach.

As the period profits are modelled "outside" the structural estimation, I am able to identify the dispersion parameter $\sigma_{\mathscr{E}}$. Therefore, I also present the estimates in monetary values (thousand of reais $(\mathrm{R} \$)$ ) in Table 12 .

Table 12 - Structural Parameters (Monetary Cost, Anually) - Top 5 Markets

\begin{tabular}{lccccc}
\hline \hline \multirow{2}{*}{ Variables } & Local Markets & & & & \\
\cline { 2 - 6 } & $\begin{array}{c}\text { Vila } \\
\text { Mariana }\end{array}$ & Pinheiros & Lapa & Mooca & $\begin{array}{c}\text { Campo } \\
\text { Limpo }\end{array}$ \\
\hline delay & $-19,843.40$ & $-85,299.91$ & $-13,188.06$ & $-12,720.52$ & $-107,628.27$ \\
& {$[6,898.51]$} & {$[54,907.53]$} & {$[14,122.44]$} & {$[18,142.58]$} & {$[41,174.28]$} \\
LAND & -975.05 & -608.64 & -188.71 & -122.62 & -275.68 \\
& {$[262.02]$} & {$[547.50]$} & {$[320.03]$} & {$[209.11]$} & {$[1,934.45]$} \\
Operational Costs & $-1,265.61$ & $-4,281.89$ & -409.58 .79 & $-1,788.09$ & $-6,352.19$ \\
(Intercept) & {$[347.29]$} & {$[931.57]$} & {$[247.04]$} & {$[439.99]$} & {$[2,352.22]$} \\
\hline Year FE & Yes & Yes & Yes & Yes & Yes \\
Developer/Market FE & Yes & Yes & Yes & Yes & Yes \\
\hline \hline
\end{tabular}

Note: Estimated parameters are measured in thousands of reais (x R \$1000). All the estimations include developer dummies, and year dummies. Standard-errors were calculated from 50 block bootstraps of beliefs (CCPs) and are shown in brackets.

For the Top markets of the city, in number of developments launched, the average estimated red tape costs due to approval delays is about $\mathrm{R} \$ 47$ millions annually by the entrant firms. The average operational cost in these markets is about $R \$ 3$ millions. This upfront cost summed up other important costs that I do not include in the estimation, 
such as other licenses and authorizations, payments due to Zoning Law or compensations, besides legal components to simply exert the activity.

\subsection{Discussion and Further Work}

These findings evidence and corroborate that the bureaucracy in the process to approve the construction of new residences play an important role in the real estate activity in the city of São Paulo. Quantitatively, the implied cost on developers are not negligible and substantial. It is also consistent with previous anecdotal evidence (ESTADAO, 2014).

The data used in this study covered the period of the most intense activity in the housing market in the city. With new residential developments being launched constantly, the bureaucracy became more evident and the claims of real estate industry became stronger. At some point, this mismatch between public and private sector led to major corruption scandals, which I cited before. In addition, this period also covered an important transition in the urban thinking of the city, such as urban mobility. These both events have motivated the Prefecture of São Paulo to enact a new Master Plan in 2014 and a new Zoning Law in 2016. In particular for this study, it also declared a new Building Code in 2017 to ensure a faster and more transparent procedure in the residential approval process.

The next steps of this study are to explore counterfactual simulations in which the stringency of regulation, through the approval delay, is evaluated. In this setting, I have to solve the model for the conditional choice probabilities and observe the impacts of the changes on the delay variable on the expected payoff and then on apartment prices. This will allow me to quantify the effect of regulation on the number of firms and the price. Ultimately, I can compute the changes in welfare under each counterfactual scenario. These future results may provide important insights for this urban policy transition process in the city. 



\section{Conclusion}

This paper aimed to analyze how the real estate activity is affected by competition and municipal land use regulation. To my knowledge, it is the first study to explicit model the interactions of real estate developers using a game theoretic approach. I used a unique data set assembled for the city of São Paulo and, from it, I employed a joint entry-decision game, in which after entry, firms compete in prices.

My empirical strategy was firstly to document the competition and regulation effects from reduced forms regressions, and then to recover the structural parameters of interest. I find that the municipal regulation in São Paulo, during the period, positively affected the house prices. The areas where residential projects faced more severe regulation in the prior period receive fewer residences and developments in the present, suggesting that firms refrain from entering these regions. The results in the structural estimation also indicate a large monetary cost due to delays in the approval process. These red tape costs have an average estimated value of $\mathrm{R} \$ 47$ millions by entrant for the main markets of the city.

The study also contributes to a considerable strand of the urban economics literature on the land use regulation effects. Unlike previous studies, the data allowed me to observe the municipal regulatory stringency at the residential development level. This granularity generated a large spatial heterogeneity among firms over time, which helped a better identification of the structural findings. Future work will deal with counterfactual scenarios in which the regulation can be analyzed in welfare terms. The results may provide useful insights for the current debate on urban policy changes that the city of São Paulo has faced. 



\section{Bibliography}

AGUIRREGABIRIA, V.; HO, C.-Y. A dynamic oligopoly game of the us airline industry: Estimation and policy experiments. Journal of Econometrics, Elsevier, v. 168, n. 1, p. 156-173, 2012. Citado 4 vezes nas páginas 18, 38, 41, and 47.

AGUIRREGABIRIA, V.; MIRA, P. Swapping the nested fixed point algorithm: A class of estimators for discrete markov decision models. Econometrica, Wiley Online Library, v. 70, n. 4, p. 1519-1543, 2002. Citado na página 18.

ARCIDIACONO, P.; MILLER, R. A. Conditional choice probability estimation of dynamic discrete choice models with unobserved heterogeneity. Econometrica, Wiley Online Library, v. 79, n. 6, p. 1823-1867, 2011. Citado na página 52.

ARDICIACONO, P. et al. Estimation of dynamic discrete choice models in continuous time with an application to retail competition. Review of Economic Studies, forthcoming, 2015. Citado na página 17.

BAJARI, P. et al. Estimating static models of strategic interactions. Journal of Business E Economic Statistics, Taylor \& Francis, v. 28, n. 4, p. 469-482, 2010. Citado 3 vezes nas páginas 18, 35, and 44.

BALL, M. Markets and the structure of the housebuilding industry: An international perspective. Urban Studies, SAGE Publications, v. 40, n. 5-6, p. 897-916, 2003. Citado na página 33.

BARWICK, P. J.; PATHAK, P. A. The costs of free entry: an empirical study of real estate agents in greater boston. The RAND Journal of Economics, Wiley Online Library, v. 46, n. 1, p. 103-145, 2015. Citado na página 17.

BERRY, S.; LEVINSOHN, J.; PAKES, A. Automobile prices in market equilibrium. Econometrica, JSTOR, p. 841-890, 1995. Citado 3 vezes nas páginas 18, 41, and 47.

BERRY, S. T. Estimating discrete-choice models of product differentiation. The RAND Journal of Economics, JSTOR, p. 242-262, 1994. Citado 2 vezes nas páginas 38 and 41.

BERTAUD, A.; BRUECKNER, J. K. Analyzing building-height restrictions: predicted impacts and welfare costs. Regional Science and Urban Economics, Elsevier, v. 35, n. 2, p. 109-125, 2005. Citado na página 18.

BERTAUD, A.; MALPEZZI, S. Measuring the costs and benefits of urban land use regulation: a simple model with an application to malaysia. Journal of Housing Economics, Elsevier, v. 10, n. 3, p. 393-418, 2001. Citado na página 18.

BIDERMAN, C. Forças de aglomeração e expulsão na grande São Paulo. Tese (Doutorado) - Fundação Getúlio Vargas, 2001. Citado na página 21.

COLLARD-WEXLER, A. Demand fluctuations in the ready-mix concrete industry. Econometrica, Wiley Online Library, v. 81, n. 3, p. 1003-1037, 2013. Citado 2 vezes nas páginas 17 and 52. 
CUNHA, C. d. A. e. Análise dos fatores que afetam as Estratégias das Incorporadoras e Construtoras Imóveis Residenciais na Cidade do Rio de Janeiro. Tese (Doutorado) PUC-Rio, 2014. Citado na página 26.

DORASZELSKI, U.; SATTERTHWAITE, M. Computable markov-perfect industry dynamics. The RAND Journal of Economics, Wiley Online Library, v. 41, n. 2, p. 215-243, 2010. Citado na página 35.

DRAGANSKA, M.; MAZZEO, M.; SEIM, K. Beyond plain vanilla: Modeling joint product assortment and pricing decisions. Quantitative Marketing and Economics, Springer, v. 7, n. 2, p. 105-146, 2009. Citado 2 vezes nas páginas 18 and 41.

ESTADAO. Burocracia causa atraso na entrega de imóveis em SP. 2011. [Online; accessed 19-April-2017]. Disponível em: <http://bit.ly/2ry0qj8>. Citado na página 19.

ESTADAO. Investigação desmonta esquema de fraude na Prefeitura. 2013. [Online; accessed 09-May-2017]. Disponível em: < http://bit.ly/2rBgC43>. Citado na página 19.

ESTADAO. Burocracia eleva em 12\% o preço dos imóveis. 2014. [Online; accessed 19-April-2017]. Disponível em: <http://bit.ly/2q2k45T>. Citado 3 vezes nas páginas 19, 31 , and 55 .

FOLHA. Ex-funcionários da gestão Kassab são presos após investigação de Haddad. 2013. [Online; accessed 09-May-2017]. Disponível em: < http://bit.ly/2qzoh4Y>. Citado na página 19.

FU, Y.; SOMERVILLE, C. T. Site density restrictions: measurement and empirical analysis. Journal of Urban Economics, Elsevier, v. 49, n. 2, p. 404-423, 2001. Citado na página 18.

GARCES, P.; PIRES, C. P. et al. New housing supply: what do we know and how can we learn more. [S.l.], 2011. Citado na página 17.

GLAESER, E. L.; GYOURKO, J.; SAKS, R. Why is manhattan so expensive? regulation and the rise in housing prices. Journal of Law and Economics, JSTOR, v. 48, n. 2, p. 331-369, 2005. Citado na página 39.

GLAESER, E. L.; WARD, B. A. The causes and consequences of land use regulation: Evidence from greater boston. Journal of Urban Economics, Elsevier, v. 65, n. 3, p. 265-278, 2009. Citado na página 17.

GNAGEY, M. et al. Heterogeneous developers, spatial interactions, and land development outcomes under uncertainty. In: AGRICULTURAL AND APPLIED ECONOMICS ASSOCIATION. 2012 Annual Meeting, August 12-14, 2012, Seattle, Washington. [S.1.], 2012. Citado na página 17.

GYOURKO, J.; MOLLOY, R. Regulation and housing supply. [S.1.], 2014. Citado na página 18.

HECKMAN, J. J. The incidental parameters problem and the problem of initial conditions in estimating a discrete time-discrete data stochastic process. Mit Press, 1981. Citado na página 52. 
HOTZ, V. J.; MILLER, R. A. Conditional choice probabilities and the estimation of dynamic models. The Review of Economic Studies, Oxford University Press, v. 60, n. 3, p. 497-529, 1993. Citado 2 vezes nas páginas 18 and 43.

HOYLER, T. Incorporação imobiliária e intermediação de interesses em São Paulo. Tese (Doutorado) — Universidade de São Paulo, 2014. Citado 3 vezes nas páginas 21, 23, and 63 .

IGAMI, M. Estimating the innovator's dilemma: Structural analysis of creative destruction in the hard disk drive industry, 1981-1998. Journal of Political Economy, forthcoming, 2015. Citado na página 17.

JIA, P. What happens when wal-mart comes to town: An empirical analysis of the discount retailing industry. Econometrica, Wiley Online Library, v. 76, n. 6, p. 1263-1316, 2008. Citado na página 17.

KALOUPTSIDI, M. Time to build and fluctuations in bulk shipping. The American Economic Review, American Economic Association, v. 104, n. 2, p. 564-608, 2014. Citado na página 17.

LIN, H. Quality choice and market structure: A dynamic analysis of nursing home oligopolies. International Economic Review, Wiley Online Library, v. 56, n. 4, p. 1261-1290, 2015. Citado na página 52.

MAYER, C. J.; SOMERVILLE, C. T. Land use regulation and new construction. Regional Science and Urban Economics, Elsevier, v. 30, n. 6, p. 639-662, 2000. Citado 2 vezes nas páginas 17 and 19.

NEVO, A. Measuring market power in the ready-to-eat cereal industry. Econometrica, Wiley Online Library, v. 69, n. 2, p. 307-342, 2001. Citado 2 vezes nas páginas 18 and 41.

NISHIDA, M. The costs of zoning regulations in retail chains: the case of the city planning act of 1968 in japan. Journal of Regulatory Economics, Springer, v. 45, n. 3, p. 305-328, 2014. Citado na página 17.

PESENDORFER, M.; SCHMIDT-DENGLER, P. Identification and estimation of dynamic games. [S.l.], 2003. Citado na página 36.

PESENDORFER, M.; SCHMIDT-DENGLER, P. Asymptotic least squares estimators for dynamic games. The Review of Economic Studies, Oxford University Press, v. 75, n. 3, p. 901-928, 2008. Citado na página 44.

QUIGLEY, J. M.; RAPHAEL, S. Regulation and the high cost of housing in california. The American Economic Review, JSTOR, v. 95, n. 2, p. 323-328, 2005. Citado na página 17.

SANCHES, F. A. M.; JUNIOR, D. S.; SRISUMA, S. Bank privatization and market structure of the banking industry: Evidence from a dynamic structural model. The RAND Journal of Economics, R\&R, 2016. Citado 2 vezes nas páginas 17 and 52.

SANCHES, F. A. M.; JUNIOR, D. S.; SRISUMA, S. Ordinary least squares estimation for a dynamic game. International Economic Review, forthcoming, 2016. Citado na página 45 . 
SMUL-SP. Guia de Aprovação de Solicitação de Alvará para Aprovação e/ou Execução de Edificação de Uso Residencial. 2016. < http://bit.ly/2qD2cAn>. [Online; accessed 19-April-2017]. Citado na página 23.

SP, P. Código de Obras e Edificações - COE - LEI No 11.228/92. 1992. [Online; accessed 19-April-2017]. Disponível em: <http://bit.ly/2qYhLWf $>$. Citado na página 22.

SUZUKI, J. Land use regulation as a barrier to entry: Evidence from the texas lodging industry. International Economic Review, Wiley Online Library, v. 54, n. 2, p. 495-523, 2013. Citado na página 17.

SWEETING, A. Dynamic product positioning in differentiated product markets:

The effect of fees for musical performance rights on the commercial radio industry.

Econometrica, Wiley Online Library, v. 81, n. 5, p. 1763-1803, 2013. Citado 3 vezes nas páginas 17, 18, and 47.

THOMADSEN, R. The effect of ownership structure on prices in geographically differentiated industries. The RAND Journal of Economics, JSTOR, p. 908-929, 2005. Citado na página 18.

TURNER, M. A.; HAUGHWOUT, A.; KLAAUW, W. V. D. Land use regulation and welfare. Econometrica, Wiley Online Library, v. 82, n. 4, p. 1341-1403, 2014. Citado na página 17.

VALOR. Ministério de São Paulo denuncia Aref e filha por lavagem de dinheiro. 2013. [Online; accessed 09-May-2017]. Disponível em: <http://bit.ly/2pZsqMk>. Citado na página 19.

WISSENBACH, T. C. A cidade e o mercado imobiliário: uma análise da incorporação residencial paulistana entre 1992 e 200\%. Tese (Doutorado) - Universidade de São Paulo, 2008. Citado na página 26. 


\section{APPENDIX A - Data Construction}

I use the Embraesp data set version compiled by the Center for Metropolitan Studies (CMS) to assess the universe of residential developments in the city. ${ }^{1}$ This version was constructed by and used in Hoyler (2014) and there are important improvements. The most relevant to my study is the uniformity of developers' names. The CMS data systematized this variable, considering some mergers in the real estate sector over the years. This was done by changing the name of the acquired developer for the acquirer firm, based on market information. In addition, when a developer has a subsidiary, for example that is focused on lower-middle class residences, the developer's name in the data is the holding's name. In addition, all prices are adjusted for inflation (using IGP-DI of 2013, the last year of the sample).

Each development in the data has the code registered in the property tax inventory, which is a unique identifier for each parcel of land in the city (i.e., each sector, block and lot (setor/quadra/lote) in the City tax records). The "São Paulo Municipal System of Proceedings" (SIMPROC) online platform allows citizens to see the progress of any official process request for the Prefecture, which includes authorizations, licensing, issuance of documents, etc. Therefore, I collect all documents requested by developers using the property code and extracting information from a SIMPROC-linked website for documents related to works and buildings (https://www.prefeitura.sp.gov.br/deolhonaobra/). Each document has a completed form with the request (usually by a developer representative) and the corresponding issuance by the Prefecture. Both contain information and descriptions about the project.

I focus on the two permits cited in the text ("Alvará de Aprovação de Edificação Nova" and "Alvará de Execução de Edificação Nova") because they are responsible for the largest delays in the data. There are two obstacles to searching through projects on the website and identifying the correct ones. First, a development usually has more than one code associated with it. This happen because the building may be on a land lot with different codes (for instance, in land lots that include two blocks in different streets or with more than one property owner). Also, even considering only these two licenses, each one of them can undergo modifications (for example, if the Prefecture disapproves the request and the firm appeals the decision or if the firm makes adjustments to the original application).

To circumvent these problems, I use the document description to identify the codes associated with the same development, and then I extract information of the documents

\footnotetext{
${ }^{1}$ This data set can be found at http://www.fflch.usp.br/centrodametropole/en/
} 
related to those codes. Regarding the second difficulty, in such cases, new licenses are issued named "Modifying Project" and, fortunately, they contain the original document number, so I identify all related codes for the same development.

After I merge the data set with the permits to the Embraesp data set (CMS version), I construct several variables and use some of them in Descriptive and Reduced Form Analysis and the Estimations. From the document descriptions, I search the text with regular expressions to create indicators for \{demolition, area donation, environmental compensation $(E N V)$, sewage network $\}$. For the $\{$ delay\}, I only withdraw the date from the request form and the issuance form and take the difference between them. In some documents, these dates are not available in the exact field of the form, but they are in the text, so I also use regular expressions in such cases.

Finally, to construct the other variables that are in the fixed cost function and the CCP estimation, $\{L A N D, Z O N E\}$, I merge the data set with two other data sets: i) the one with information for the Charge for Additional Building Rights ("Outorga Onerosa") and ii) the 2016 City property tax inventory. Both have recently been made public and can be accessed at: http://geosampa.prefeitura.sp.gov.br. 


\section{APPENDIX B - Potential Entrants by Market}

Next table includes the names of the developers used in the estimation. I consider the 19 largest firms in number of apartments launched in each market from 2000 to 2013. All other firms were grouped in one local firm (market-specific). Therefore, each market has a pool of 20 potential entrants. 


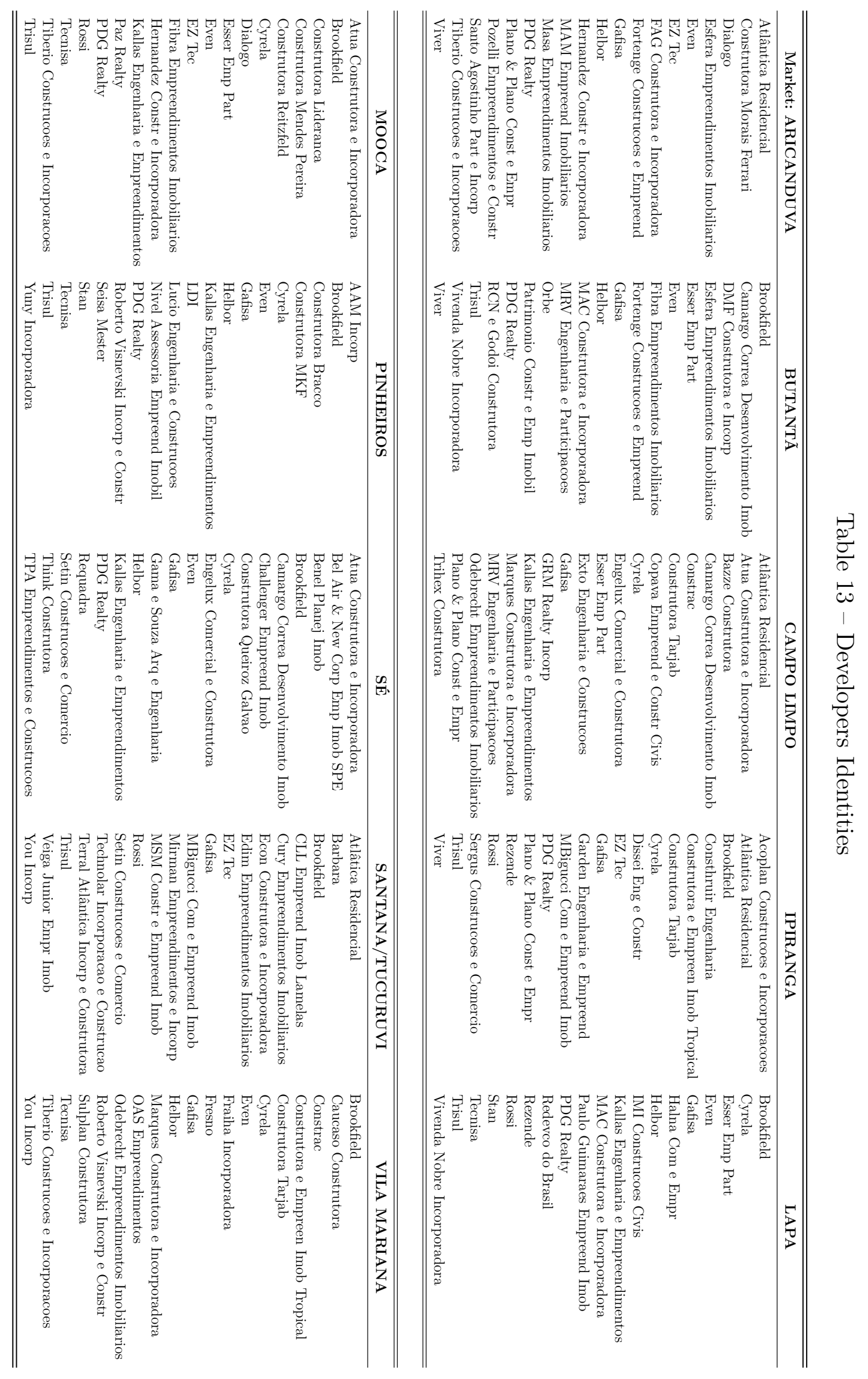

